Journal of

Education and Practice (JEP)

EXTENT OF INTEGRATION OF INFORMATION AND COMMUNICATION TECHNOLOGIES IN CLASSROOM INSTRUCTION IN NEPAD E-SCHOOLS, KENYA

Jackson Mobisa Mogeni, Prof. Samson R. Ondigi and Dr. Bernard C. Mugo

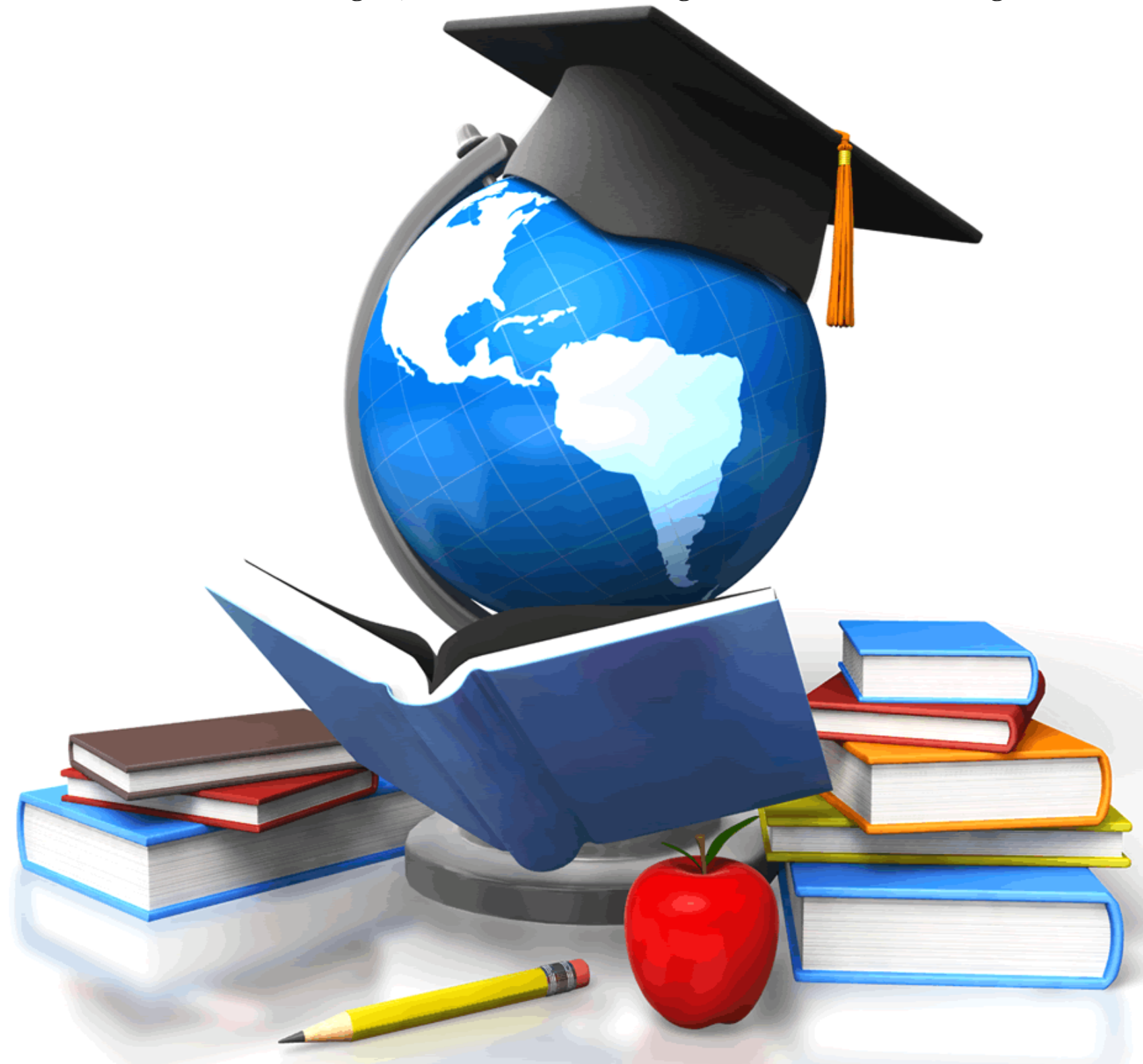

CARI 


\title{
Extent of Integration of Information and Communication Technologies in Classroom Instruction in Nepad E-Schools, Kenya
}

\author{
1*Jackson Mobisa Mogeni \\ Post Graduate Student, School of Education, Kenyatta University \\ *Corresponding Author's E-mail: jmmogeni@gmail.com \\ ${ }^{2}$ Prof. Samson R. Ondigi \\ Associate Professor, School of Education, Kenyatta University \\ ${ }^{3}$ Dr. Bernard C. Mugo \\ Lecturer, School of Education, Kenyatta University
}

\begin{abstract}
Purpose: The purpose of this study was to determine the extent to which teachers integrate ICTs in classroom teaching and learning in NEPAD e-Schools, Kenya.

Methodology: This study adopted a descriptive survey design and collected quantitative and qualitative data using mixed methods. The target population were 256 teachers. Sampling was done employing a mixture of techniques; stratified sampling to pick 5 schools, and purposive sampling to pick 110 teachers. Data were collected using questionnaire, resources checklist and observation. Data were coded, and run for descriptive analysis; including frequencies, percentages, measures of central tendency and measures of variability using SPSS version 22.0. Data were then presented aided by notes, frequency tables, percentages, charts and figures.

Findings: Schools had functional, but unreliable electricity, and had altered ICTs to different degrees and directions; some had either been replaced or totally lost. The schools faced maintenance challenges; impeding ICTs integration in instruction. More teachers infrequently, or rarely integrated ICTs than those who did so regularly. The mean frequency of ICTs integration was once a month. Computers and word processing were teachers' most preferred ICT tools. Teachers mainly used ICTs to illustrate main ideas during lessons. Subject content mostly determined choice and use of instructional ICTs. Most teachers found ICTs integration being generally easy, had above average proficiency in integrating ICTs, and could apply their technological, pedagogical and content knowledge well. The study concludes that teachers are alienated from integrating ICTs frequently owing to their location. Therefore, there is need to designate more places for teachers to be unimpeded from accessing and integrating ICTs.

Unique contribution to theory, practice and policy: The study lends insights to other instructional ICTs initiatives to reminisce and study as they initiate or expand their projects; like provision and sustenance of infrastructure, tools, and support services. It also contributes to the body of knowledge in educational technology, which might inform theory and practice in ICTs integration. It could also inform the development of best practices in application and integration of ICTs in instruction.
\end{abstract}

Keywords: $e-S c h o o l s$, ICTs, Instruction, Integration, NEPAD. 
Journal of Education and Practice

ISSN 2520-467X (online)

Vol.4, Issue No.3, pp 56 - 87, 2020

$\underline{\text { www.carijournals.org }}$

\subsection{INTRODUCTION}

\subsection{Background to the Study}

Since the 1990s, Information and Communication Technologies (ICTs) have rapidly permeated different sectors of society (UNESCO, 2000). In education, they are enabling users to gather, manage, manipulate, access, and share educational ideas in various forms (Chan, 2002). For this reason, in the year 2000, the international community, at the World Education Forum in Dakar (Senegal), realized that many African and other underdeveloped countries were lagging far behind in their uptake of ICTs in all sectors and decided to assist them address the problem. Education was identified as one of the priority sectors that required the uptake of ICTs to enable it prepare learners for job market of the $21^{\text {st }}$ century. Towards this end, and awake to the fiscal implications, the forum urged for a multi-sectorial, multi-agency approach to the lodging of the ICTs, since education is intricate and multifaceted. The forum recommended pilot initiatives to enable proper adjustments before full roll-outs (UNESCO, 2000).

Later that year, the United Nations General Assembly (UNGA) furthered the Dakar drive through the United Nations (UN) Millennium Declaration of the Millennium Development Goals (MDGs). The UNGA reiterated that global development could only be realized across board; including the education sector; through concerted efforts of both public and private partnerships (UNGA, 2000). Hence, taking cue from the declaration, Africa started realizing a number of multi-sectorial, multi-agency initiatives towards digitalization and ICTs uptake. One of them was the New Partnership for Africa's Development (NEPAD) joint ICTs project.

Led by the African Union (AU), in 2003, NEPAD prioritized human development mainly in health, education, science and technology, and skills development and identified ICTs as the vehicle for hastening the desired change (UNESCO, 2005). The NEPAD e-Schools initiative was born as a priority continental undertaking to digitalize schools and equip learners with skills to enable them contribute effectually in the global information society. The ultimate goal was to digitalize all public schools in Africa within ten years of its inception. The project was launched in 2005 with a goal to cover all high schools within five years. Demonstrations were initiated over 12-18 months in 96 model schools across 16 countries before hand-over to the respective states for full scale roll-out (NEPAD e-Africa Commission, 2007).

In Kenya, NEPAD equipped six model secondary schools between 2005 and 2006, (MoE Kenya, 2008). At time, the government was formulating policies and strategies for ICTs in education, developing e-learning delivery systems, building capacity, and developing requisite infrastructure and institutional management systems (GoK, 2005). For instance, the Kenya Education Sector Support Programme (KESSP) of 2005-2010, was meant to ensure provision of adequate and quality educational facilities for teacher training, in-service programmes to upgrade teachers' skills, and revision of teacher education curricular to embrace skills in ICTs (MoEST, 2005). The NEPAD e-Schools model was to be emulated and replicated across the country after piloting and take-over by the government.

From onset, the programme was envisaged to be holistically executed, including components of infrastructure (computers, communications, networking, power, etc.), training for teachers, content and curriculum development, effort towards community involvement and buy-in, stake-holding and ownership of the process, organization and management of the project, partnership issues, and financial and sustainability issues among others (NEPAD e-Africa Commission, 2007). Part of the programme's initial objectives was to: 
Journal of Education and Practice

ISSN 2520-467X (online)

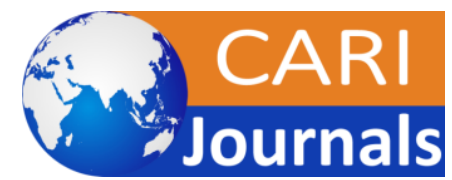

Vol.4, Issue No.3, pp 56-87, 2020

www.carijournals.org

i. Provide ICT skills and knowledge to learners that will enable them to function in the emerging Information Society and Knowledge Economy;

ii. Provide teachers with ICT skills to enable them to use ICTs as tools to enhance teaching and learning; and

iii. Provide school managers with ICT skills to facilitate efficient management and administration in schools.

Therefore, after equipping the model schools, the NEPAD secretariat armed the principal and several teachers per school with some basic skills in ICTs. The aim was to gradually but ultimately equip all teachers in the model schools with the essential skills as digitalization of instruction took root (MoE, Kenya; 2008). The hope was that the initially selected teachers would cascade the training down to their staff mates and, later, other new teachers joining the schools. This trend was envisaged to continue across the country once the programme was fully implemented. Table 1 shows the basic infrastructure and systems that were required to be delivered and installed in the model schools by the NEPAD-contracted consortia.

Table 1: Infrastructure and Systems Expected to be Deployed by Consortia

\begin{tabular}{|c|c|c|}
\hline No. & Components & Functionality/Purpose \\
\hline 1. & Server & To support Network and Workstations \\
\hline 2. & Multimedia System & Adaptation and production of teaching materials \\
\hline 3. & 23 Desktop Computers & $\begin{array}{l}20 \text { to support student's laboratory and } 3 \text { to support } \\
\text { administration }\end{array}$ \\
\hline 4. & e-Content Application & Learn things Curricula Application \\
\hline 5. & Smart Board & Given to Microsoft Consortium supported \\
\hline 6. & $\begin{array}{l}\text { Fully established LAN (Routers } \\
\text { \& Average } 24 \text { Access Points) }\end{array}$ & Options were Cable Connect \\
\hline 7. & $\begin{array}{l}\text { Fully established Internet } \\
\text { connectivity and access }\end{array}$ & $\begin{array}{l}\text { Consortia firms made commitment to support } \\
\text { such connectivity (Vista Technology) covering } \\
\text { over } 50 \mathrm{Kms}\end{array}$ \\
\hline 8. & $\mathrm{~A} \mathrm{Te}$ & DSTV \\
\hline 9. & Printers & $\begin{array}{l}\text { Network, Lab, Media room, and administration } \\
\text { office }\end{array}$ \\
\hline 10. & $\begin{array}{l}\text { Multi-functional } \\
\text { Copier/Scanner/Fax }\end{array}$ & $\begin{array}{l}\text { To support teaching/learning materials; to support } \\
\text { administrative records and communication }\end{array}$ \\
\hline 11. & Projector & $\begin{array}{l}\text { To support demonstration and illustration of } \\
\text { lessons and to maximize use of one machine to } \\
\text { deliver lessons to larger classes/audience }\end{array}$ \\
\hline
\end{tabular}

Source: MoE, Kenya (2008)

However, signs on the ground show that the roll-out, in its original form or otherwise, is yet to happen, despite several studies having rated it highly as noble and likely to enhance instruction in Kenya. For instance, Mugo (2007); Ogutu (2008); Ayere, Odera \& Agak (2010); and Nyagowa, Ocholla \& Mutula (2012), concluded that, despite the challenges faced by the model schools, the ICTs in the schools were enhancing quality educational processes and classroom interactions. The e-Schools were even reporting improved performance in national examinations, which was corroborated by data provided by MoE (2008). 
Yet, whether the e-Schools project stagnated, is running late, or perhaps was abandoned altogether, it is expected that the ICTs initially provided and/or thereafter added continue to transform instruction in the model schools. The schools would be expected to be preparing learners for the digital world and workplace of the $21^{\text {st }}$ century. Hence, there was need to determine the extent to which this was occurring and the current role of ICTs in instruction in the model schools. This, therefore, inspired the institution of this study to determine the extent to which teachers integrate ICTs in instruction in the NEPAD e-Schools, Kenya.

\subsection{Statement of the Problem}

Several studies done on the NEPAD e-Schools programme in Kenya in the past endorsed it as good, and significantly potential to succeed if fully effected. However, the studies were done in the try-out and early post-try-out phases. Much time has since passed and it is not clear what is impeding the digitalization roll-out to other public secondary schools. This ignites the urge to question the state's continued commitment towards digitalization and modernization of instruction in public schools. One may also wish to enquire whether the challenges identified by earlier studies in the model schools are the ones yet to be addressed and the government fears they could recur across-board if the roll-out happens.

Be that as it may, the pertinent question is; after piloting ended, what direction did the model schools take in terms of application and maintenance of ICTs, and management of instructional processes among others? What trajectory did the integration process take? Is integration still on-going? Are teachers still applying ICTs in teaching? If so, how and to what extent? There was, therefore, need for a current study to determine the trajectory of digitalization and ICTs integration in these schools. Moreover, some of the previous studies were limited in scope by looking at selected subjects; or mainly at the chances of success of the project; while others compared and contrasted the model schools with the non-model ones in terms of resources, and performance among others. Yet, with piloting having long ended, little has been done to establish how the schools are faring; a need that the present study sought to address.

\subsection{Purpose of the Study}

The purpose of this study was to determine the extent to which teachers integrate ICTs in classroom teaching and learning in NEPAD e-Schools, Kenya.

\section{Objectives of the Study}

Specifically, the objectives that guided this study were to:

i. Determine the adequacy of the resources and infrastructure available in NEPAD eSchools to support the integration of ICTs in instruction.

ii. Establish teachers' frequency of integrating ICTs into the instructional process.

iii. Establish the ICTs that are mostly preferred and used by teachers during instruction.

iv. Discover teachers' practical application of ICTs in instruction. 
Journal of Education and Practice

ISSN 2520-467X (online)

Vol.4, Issue No.3, pp $56-87,2020$

www.carijournals.org

\subsection{Theoretical Framework}

This study was informed by two theories, namely: Unified Theory of Acceptance and Use of Technology (UTAUT) by Venkatesh, Morris, Davis \& Davis (2003); and Technological, Pedagogical and Content Knowledge (TPACK) Theory by Mishra and Koehler (2008).

\section{Unified Theory of Acceptance and Use of Technology (UTAUT)}

Adapted from the Theory of Reasoned Action by Ajzen and Fisbein (1980), UTAUT is advanced by Venkatesh et al. (2003). UTAUT expounds the Technology Acceptance Model (TAM) as proposed by Davis, et al. (1989) and upgraded to TAM 2 by Venkatesh (2000), and Venkatesh \& Davis (2000). UTAUT later informs the improvements proposed in TAM 3 by Venkatesh \& Bala (2008). UTAUT posits that a person's behavioural intention to use, and eventual adoption of new technologies is influenced by the attitude one holds towards the technologies. Davis et al. (1989) and Davis (1989) define attitude as a person's positive or negative feeling about executing a target behavior, while behavioural intention refers to the degree to which one has formulated conscious plans to execute or not execute a specified future behaviour. Hence, teachers' attitude towards ICTs will lead them to accept and eventually apply ICTs often, or to reject and fail to integrate them. If their attitude is positive, they will often willfully plan and, eventually, integrate ICTs. If negative, they will often purposely ignore and, finally, fail to integrate the ICTs.

According to UTAUT, attitude is influenced by, most notably, perceived usefulness (PU) and perceived ease of use (PEOU) of ICTs. Perceived usefulness is the degree to which one believes that using a certain system would enhance his/her job performance or efficiency, while perceived ease of use is the degree to which one believes that using a certain technology would be free from effort and/or discomfort. If teachers perceive that ICTs are useful to their teaching, they will tend to deliberately integrate them. But if they perceive the opposite, the reverse is likely to happen. Again, if teachers perceive that ICTs are easy to use or integrate, then they will develop a liking for them. But if they perceive otherwise, the contrary is likely to happen. This theory contributed towards exploring and understanding teachers' perceived ease of use of ICTs in their teaching.

\section{Technological, Pedagogical and Content Knowledge (TPACK) Theory}

This theory highlights the necessary knowledge by teachers for a productive integration of technologies in teaching. According to Mishra and Koehler (2008), three elements constitute an effective integration of ICTs in teaching, namely; content, pedagogical, and technological knowledge. They argue that teachers' subject (content) knowledge and pedagogical skills are not mutually exclusive but rather interconnected. The two interact and interrelate, and overlap with technology to create three intersections: Technological Pedagogical Knowledge, Technological Content Knowledge, and Pedagogical Content Knowledge. Ultimately, the three elements and intersections form a mutual convergence - the Technological, Pedagogical, and Content Knowledge (TPACK) of a teacher.

The import of TPACK is that even ICTs require thoughtful entwining of technology, pedagogy and content knowledge for a fruitful integration of ICTs. Through TPACK, this study recognizes the complex interrelationship among the different elements, which are contextually bound for a successful integration of ICTs. A concurrent and proper alliance of these elements makes a big difference in realizing the goals of investing in educational ICTs. For instance, if 
Journal of Education and Practice

ISSN 2520-467X (online)

Vol.4, Issue No.3, pp $56-87,2020$

www.carijournals.org

teachers have the necessary technological, pedagogical and content knowledge and training, the school setting is good, and adequate ICTs are availed, integration of ICTs is enhanced.

\subsection{LITERATURE REVIEW}

\subsection{Teacher-related Factors Influencing Integration of Instructional ICTs}

\section{Teacher Characteristics}

Teacher characteristics greatly influence any educational improvement or innovation efforts. Studies have indicated that teachers' gender (or sex) can influence the adoption of ICTs, especially how teachers adopt and use them (Vekiri \& Chronaki, 2008; Becta, 2008; Afshari et al., 2009). Studies also indicate that educational qualification (academic and professional) influences the adoption of ICTs (Schiller, 2003; Afshari et al., 2009). For teachers to productively integrate ICTs, they ought to be academically and professionally qualified.

Teachers' age and professional experience are also said to influence adoption of ICTs. Those with fewer years of experience are more likely to use ICTs in class than those with more years of experience. This is attributed, partly, to the fact that new teachers have been exposed to ICTs during their training and therefore, have more experience using them than their predecessors (Schiller, 2003; Afshari et al., 2009). Older teachers, having successfully established routines of work that meet their criteria of good teaching, are reluctant to change their practice, especially if they do not understand the rationale for change (Scott \& Usher, 2010).

Teachers' experience with ICTs for educational purposes is also cited as a factor that can influence their adoption (Schiller, 2003; Afshari et al., 2009). Experience is the length of time and instances that teachers have interacted with ICTs, and the skills they have gained during the interactions. Time is an important element in the ICTs integration process. This includes the time teachers take from first knowledge of ICTs through their integration, and the ICTs' rate of adoption (application) at a given time period among other issues (Rogers, 2003). Studies have shown differences in ICTs access and use across teachers at any time (Colley \& Comber, 2003; Vekiri \& Chronaki, 2008; Becta, 2008). This factor was also considered in this study in relation to its effect on the extent of integration of ICTs alongside other teacher characteristics.

\section{Teachers' Level of Training in Integration of ICTs in Instruction}

Scholars have noted that formal teaching in classrooms is still driven by traditional teaching practices. Teachers are still mostly helping students acquire information from textbooks and acting as the information givers (Lee, 2002). Teachers fear taking risks because they feel inadequately prepared. They can only train learners in ICTs if they themselves are literate and use them for instruction (Steketee, 2006). However, assertions abound that teachers, especially in developing countries, are not sufficiently trained to successfully integrate ICTs.

According to Farrell and Isaacs (2007), many African ICTs integration ventures focus more on the development of operational skills than on the integration of ICTs in pedagogical practice. Balanskat et al. (2006) call this inappropriate training which does not help teachers to use ICTs in classrooms and in preparing lessons. Most teachers also receive a one-time or 'one-off' training; instead of extensive, on-going exposure in ICTs; which may not be sufficient to enable them integrate ICTs appropriately (Lau \& Sim, 2008 and Trucano, 2005). Therefore, teachers should engage in both initial and on-going training to enhance their integration skills (Lau \& Sim, 2008; Boakye \& Banini, 2008). 
Journal of Education and Practice

ISSN 2520-467X (online)

Vol.4, Issue No.3, pp $56-87,2020$

www.carijournals.org

There is also need to reform the entire teacher education system instead of just trying to 'reequip' teachers with ICTs if they are to feel comfortable using ICTs, let alone integrating them successfully into their teaching. The traditional one-time teacher training workshops have not been seen as effective. Discrete, 'one-off' training events, are seen as less effective than ongoing professional development activities (Boakye \& Banini, 2008 and Trucano, 2005). According to Brinkerhoef (2006), studies have shown that quality professional training programs help teachers implement ICTs and transform their teaching. Lawless and Pellegrino (2007) stress that if training programs on application of ICTs are to be of high quality, the training period should last longer and teachers are regularly updated on new ICTs for instruction among other important activities.

\section{Availability, Sufficiency, Accessibility and Functionality of Facilities}

Some of the major determinants in the use of ICTs' in schools in most countries include: availability and consistency of supply of electricity; availability, sufficiency, and/or accessibility of ICT equipment and infrastructure, carrying capacity of computer labs in terms of both resources and users; and availability of affordable access to connectivity with acceptable bandwidth (Farrell \& Isaacs, 2007). Lack of reliable electricity supply and access to basic, affordable internet infrastructure and connectivity, for example, inhibits the use of ICTs to even provide basic access to digital content (Osakwe, 2010; Ndawula, et al., 2013). Hence, to guarantee a predictable transition to ICTs, African schools must first get reliable basic infrastructure and internet connectivity, and a steady electricity supply.

Another factor that influences the use of ICTs' in schools is the location and accessibility of the facilities. Hinostroza et al. (2005) observe that the location of ICTs in public schools is dictated by the nation's ICTs in Education policy. In most developing countries most ICTs are located in computer labs, while in the developed ones they are located in classrooms or other places where they can be conveniently used or brought to class. Yet, the sufficiency of ICTs may also dictate their locations. In schools where the ratio of ICTs to users is large, there might be need to locate them at a central place (Mungai, 2011; Kiptalam \& Rodrigues, 2010; Wims \& Lawler, 2007). But, according to the U.S. Department of Education, National Center for Education Statistics (2010) and Statistics Canada (2012), schools with enough ICTs will tend to distribute them to places that are convenient and near to each target user since the users are not competing for the ICTs.

The pace and frequency of technological changes may also influence the use of ICTs in schools. Teachers are expected to keep up with the very fast technological changes and schools to acquire the latest ICTs for instructional use. However, schools can only budget for and allocate funds to update their ICTs if they can afford to (Roblyer, 2006). Financial constraints will also dictate the budgetary allocations for the expansion, management and sustenance of e-learning projects and ICTs (Beukes-Amiss \& Chiware, 2006; Tella, et al., 2007). Apart from that, teachers may be generally skilled and willing to integrate ICTs, but are constrained by limited and unreliable ICTs, as well as insignificant time allocated to them and their learners to use the ICTs (Tella, et al., 2007; Beukes-Amiss \& Chiware, 2006).

The capacity of schools to carry out the necessary maintenance and repair of ICTs is yet another factor in the integration process. It is very common to see schools' computer labs full of broken down computers, repairable or otherwise due to limited technical capacity (Mungai, 2011). Kiptalam and Rodrigues (2010) assert that the technical capacity to repair and maintain ICTs 
Journal of Education and Practice

ISSN 2520-467X (online)

Vol.4, Issue No.3, pp $56-87,2020$

www.carijournals.org

in schools dictates the number of ICTs available for use by teachers and learners. As a result, this bears on access to the ICTs (Bingimlas, 2009), and competition among users (Mungai, 2011). This study explored, among other factors, the availability, functionality, adequacy and accessibility of a number of ICTs expected in the schools under investigation.

\section{Teachers' Attitude towards ICTs}

According to Tella et al. (2007), teachers need to perceive the usefulness of ICTs before interrogating or altering their professional practice to adopt them. This will make them more likely to have a positive attitude toward the use of ICTs in class. Teachers also need to perceive ICTs as being easy to use at a personal level and for teaching. This will most likely also influence their attitude (Tella et al., 2007). One of the variables associated with perceived usefulness of ICTs, leading to an individual's attitude formation, is a person's perception that most people who are important to him/her think he/she should or should not adopt the ICTs. This is closely linked with the degree to which the use of ICTs is perceived to enhance one's status (or image) in one's social system, job relevance, output quality and result demonstrability. These, among other variables that are associated with perceived usefulness, eventually bear on one's attitude towards and eventual adoption of ICTs (Venkatesh \& Davis, 2000; Venkatesh, 2000; Venkatesh \& Bala, 2008).

Different studies have classified negative attitude as a barrier to teachers' use of ICTs in class. For instance, Ertmer (1999) refers to it as one of the second-order barriers alongside, beliefs, practices and resistance. Hendren (2000) - cited in Al-Alwani (2005) and Bingimlas (2009) sees it as a form of intrinsic barriers pertaining to teachers, administrators, and individuals. Becta (2004) and Bingimlas (2009) group it as one of the teacher-level barriers alongside lack of time, lack of confidence, and resistance to change. On their part, Balanskat et al. (2006) group teachers' negative attitude as one of the micro level barriers alongside teachers' approach to ICT. Another angle is presented by Pelgrum (2001) by referring to it as one of the nonmaterial obstacles to the use of ICTs alongside teachers' insufficient ICT knowledge and skills, the difficulty of integrating ICT in instruction, and insufficient teacher time.

Instruction involving ICTs has the advantage of, among others, urging learners' motivation and kindling in them a desirable attitude towards ICTs in their entire way of life (Tella et al., 2007). Rogers (2003) says that the rate of diffusion of an idea depends on how (and what) an individual or other unit of adoption that has knowledge of or experience with using the innovation communicates with another individual or other unit that is yet to have the knowledge. The nature of the information-exchange relationship between the pair determines the conditions under which information will or will not be transmitted and the effect of the information transfer. If the receivers perceive from the transmitters that an idea has, among other features, greater relative advantage, compatibility, trialability, observability, and less complexity, they will also become positive towards the innovation and desire to try it (Rogers, 2003). 
Journal of Education and Practice

ISSN 2520-467X (online)

Vol.4, Issue No.3, pp $56-87,2020$

www.carijournals.org

\subsection{Review of Past Studies on Kenyan NEPAD e-Schools and Gaps Identified}

Several studies have been done in the past on the NEPAD e-Schools in Kenya, yielding varied results. Mugo (2007), investigating integration of ICTs in the science subjects in one model school, observed that the ICTs were too few; the computers to students ratio being 1:25. The ICTs were mainly being used in teaching Computer Studies and rarely as general instructional media. The ICTs were not being accessed easily for general integration due to their location, and were lacking software and policy guidelines tailor-made for the Kenyan curriculum. Most teachers were untrained and/or unskilled in use of ICTs and, hence, rarely used them. Rapid technological changes, ICTs breakdowns, high maintenance costs, frequent power and internet connectivity interruptions, inadequate time support for teachers, lack of relevant e-Contents, and teachers' poor exposure to ICTs were part of the challenges facing teachers. However, the study covered only 7 teachers in only one school.

A year later, a study by Ogutu (2008) revealed that both students and teachers had developed a positive attitude towards the use ICTs and related accessories in the instructional process, as reflected both by the frequency of use of the ICTs and the interest indicated by the respondents. The NEPAD e-Schools were now using educational management software for various processes. However, the schools still faced some notable challenges like lack of funding to support the purchase of the technology to improve access, lack of training among teachers to adopt ICTs as teaching tools and lack of suitable e-content for various subjects.

Thereafter, Ayere, Odera \& Agak (2010) compared application of e-learning in NEPAD and non-NEPAD schools in Kenya and reported that e-learning had enhanced greatly the instructional outcomes in the model schools. The use of ICTs to teach subjects beside Computer Studies was now far more regular in NEPAD schools than in non-NEPAD ones due to the presence of internet and ICTs like LCD projectors, smart boards and e-libraries. Integration in NEPAD schools was notably distinct compared to non-NEPAD schools. All students in NEPAD schools had access to electronic materials for educational research compared to only $17 \%$ in the non-NEPAD schools. Only $53 \%$ of all students in the study schools used internet services, $90 \%$ of whom were from NEPAD schools. As a result, there was a significant difference in the way NEPAD and non-NEPAD school students used internet and e-libraries in education research. All NEPAD schools had access to internet and averagely at least 6 elibraries per school as compared to only 3 in one non-NEPAD school. NEPAD schools did better than non-NEPAD ones in national exams but this could not be linked directly to elearning.

In their study, Nyagowa, Ocholla \& Mutula (2012; 2013) evaluated the success of NEPAD pilot schools in Kenya. They established that all six schools had the basic facilities and infrastructure required to integrate ICTs in instruction, and had internet access via satellite in computer laboratories where a variable number of computers were installed. Students and teachers were also trained in the use of ICTs and they were using them for teaching and learning. Students found learning with ICTs enjoyable, which seemed to improve their performances as confirmed by examinations results in four of the schools. Hence, the study concluded that the NEPAD e-Schools project in Kenya has considerable potential for success. The study recommended that the national government and other stakeholders should continue investing in the NEPAD e-Schools project and expand it to more schools in a phased approach since the costs of deploying e-Schools at national level are very high. Public and private sectors should also be invited to participate in the expansion of ICT infrastructure for a more rapid 
Journal of Education and Practice

ISSN 2520-467X (online)

Vol.4, Issue No.3, pp $56-87,2020$

www.carijournals.org

uptake of e-Schools. The government could also lay strategies to ensure that the desired skills are incorporated in teacher in-service training, or teacher education curricula apart from enticing teachers to attend trainings (Nyagowa, Ocholla \& Mutula, 2012; 2013).

From the above reviewed studies, it is evident that the NEPAD e-Schools programme in Kenya has been variously investigated and found to be good, and having considerable potential for success if invested in and expanded to more schools nationally. However, most of these studies were done during the piloting and early years of the project. Some of the studies were also limited in scope by targeting only certain subject areas, while others were interested in the potential of the success of the project. Others were comparing and contrasting the project schools with the ones outside the project in terms of resources, performance among others. Yet, with piloting having long ended, little has been done to establish how the schools are faring after piloting and the present study sought to fill this gap.

\subsection{RESEARCH METHODOLOGY}

This study adopted a descriptive survey design. Both quantitative and qualitative data were collected using a mixture of methods. The collected data generated statistical, as well as narrative description and interpretation of events, conditions, or situations as they are (Picciano, 2004). The target population for the study was the 6 model e-Schools, and 256 teachers in the schools. A mixture of methods was used to pick the desired samples for the study. Stratified sampling was used to sample schools, while purposive sampling was used to sample teachers. Stratified sampling involves selecting samples from different sub-groups so that each subgroup is adequately represented (Wiersma \& Jurs, 2005). Purposive sampling entails selecting cases with the required information, experience or expertise, or the most desirable features with respect to the objectives of a study (Mugenda \& Mugenda, 2013). The schools were grouped into three strata: boys' only ( 2 schools), girls' only ( 3 schools) and mixed boys and girls (1 school). All the three schools in the boys' only and mixed schools strata were purposively sampled, being the only ones in their strata. In the girls' only stratum, two schools were randomly selected; ensuring that all sub-groups were represented in the study. Random sampling is applying probability to pick a portion of cases from a homogeneously qualified population (Mugenda \& Mugenda, 2013). All form three subject teachers in the sampled schools were purposively selected because they were deemed to be rich in the information being sought by this study. Sampling means selecting a subset, part or section of the population which a research intends to generalize its findings (Wiersma \& Jurs, 2005).

Data was collected using questionnaire for teachers, resources checklist and observation guide. Piloting was initially done to ascertain the ability of the instruments, and the generated items, to elicit the responses they were expected to, and to measure that which they were supposed to prior to actual data collection. The pilot study was done in the only NEPAD e-School that had remained after the sampling process. The school was excluded from the final study. The school's 10 randomly selected form three teachers participated in the pilot study. Piloting enables the researcher to identify any problems of the instruments and correct or prepare for them accordingly, aids in the testing and confirmation of reliability of instruments and generated items, and also examines the research methodology using the planned data-gathering techniques in order to ascertain the adequacy of research design overall and the functionality of data-gathering techniques in particular (Murray \& Lawrence, 2000). Validation of instruments was done to ascertain the degree to which they measured what they were supposed 
Journal of Education and Practice

ISSN 2520-467X (online)

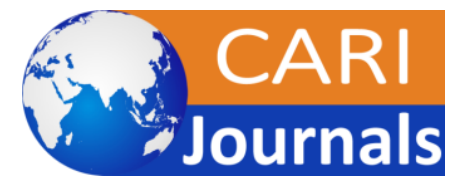

Vol.4, Issue No.3, pp 56-87, 2020

www.carijournals.org

to measure (Wiersma \& Jurs, 2005; Orodho, 2004; Hittleman \& Simon, 2006). A panel of faculty in the School of Education, Kenyatta University judged the instruments prior to piloting and their input were duly incorporated. Equivalent (parallel) forms reliability was used to test the questionnaire. Using Cronbach's alpha, the instruments' reliability was accepted at a coefficient score of $r=.75$.

The collected data were first cleaned and reduced before coding. The Statistical Product and Service Solutions or SPSS (formerly Statistical Package for the Social Sciences) version 22.0 was used to analyse the data. The quantitative data mainly generated by the resources checklist and closed items in the questionnaire; were coded and keyed into the computer. The qualitative data, mainly generated from classroom observations and open items in the questionnaire were analysed by first establishing their categories and their themes. The data were then coded, and keyed into the computer. All the coded data were thereafter run for descriptive analysis, which included frequencies, percentages, measures of central tendency and measures of variability/spread. Finally, all the analysed data were presented with the aid of appropriate notes, frequency tables, percentages, charts and figures based on the objectives of the study.

\subsection{PRESENTATION, INTERPRETATION AND DISCUSSION OF FINDINGS}

\subsection{Instruments Return Rate}

The questionnaire was administered to and returned by all the selected 110 teachers. The other instruments were administered directly by the investigator. Hence, there was $100 \%$ return rate.

\subsection{Demographic Data of the Respondents}

\section{Respondents' Gender}

Seventy $(63.6 \%)$ of the teachers and were males, while $40(36.4 \%)$ were females respectively. Therefore, we may conclude that most teachers in the e-Schools under study were males. This implies that the teaching profession is still male dominated and calls for players in the education sector to address this disparity especially through teacher training affirmative action.

\section{Respondents' Academic and Professional Qualifications}

Academic and/or professional qualification is the level of educational training that one has attained in respect to his/her qualification as a teacher. Figure 1 presents the teachers' qualifications.

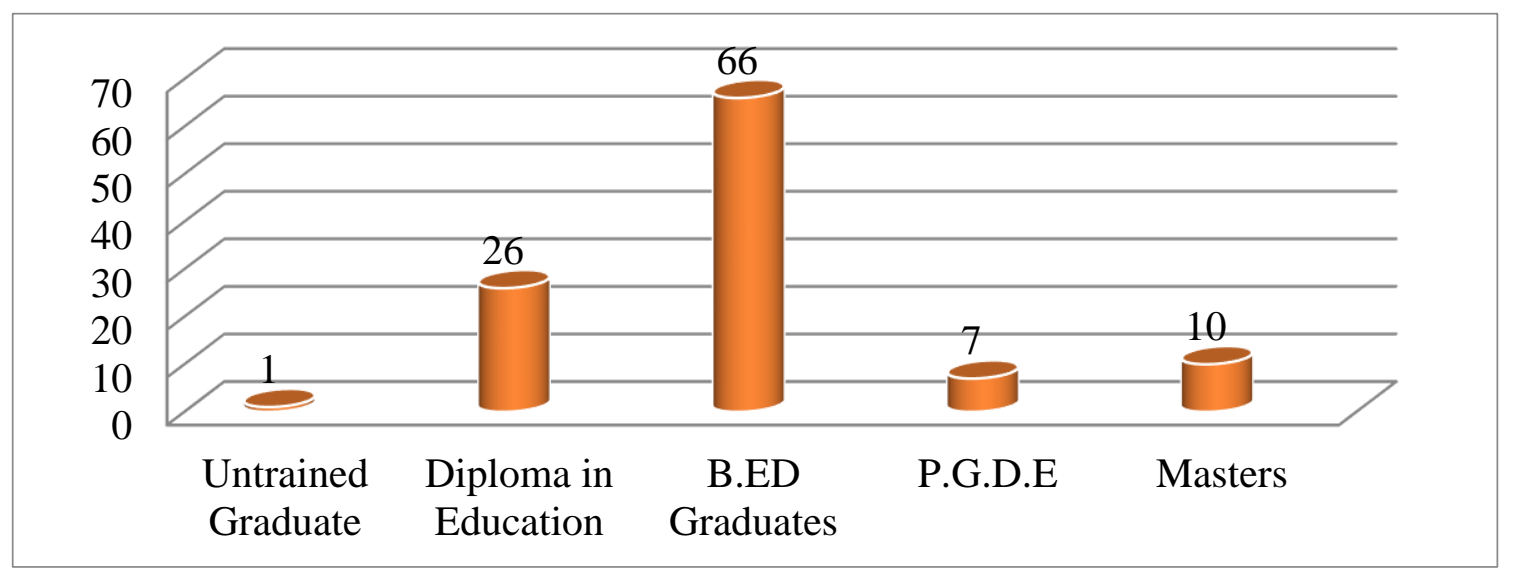

$\mathbf{N}=\mathbf{1 1 0}$ 
Journal of Education and Practice

ISSN 2520-467X (online)

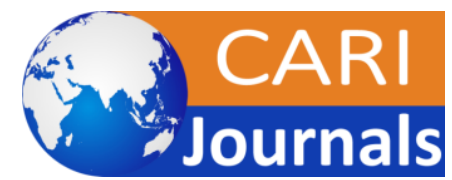

Vol.4, Issue No.3, pp 56 - 87, 2020

www.carijournals.org

\section{Figure 1: Teachers' Academic/Professional Qualifications}

Sixty-six (60.0\%) teachers were Bachelor of Education (B.ED) degree graduates, $26(23.6 \%)$ were Diploma in Education holders, 10 (9.1\%) were Masters' degree graduates (with B.ED as first degree), 7 (6.4\%) Post Graduate Diploma in Education (P.G.D.E) holders and only 1 $(0.9 \%)$ was an untrained graduate teacher. We can, therefore, conclude that at least $99 \%$ of the teachers were professionally trained and qualified.

\section{Respondents' Age Distribution and Working Experience}

Part of the demographic data sought by this study was teachers' age. Figure 2 summarizes the generated data.

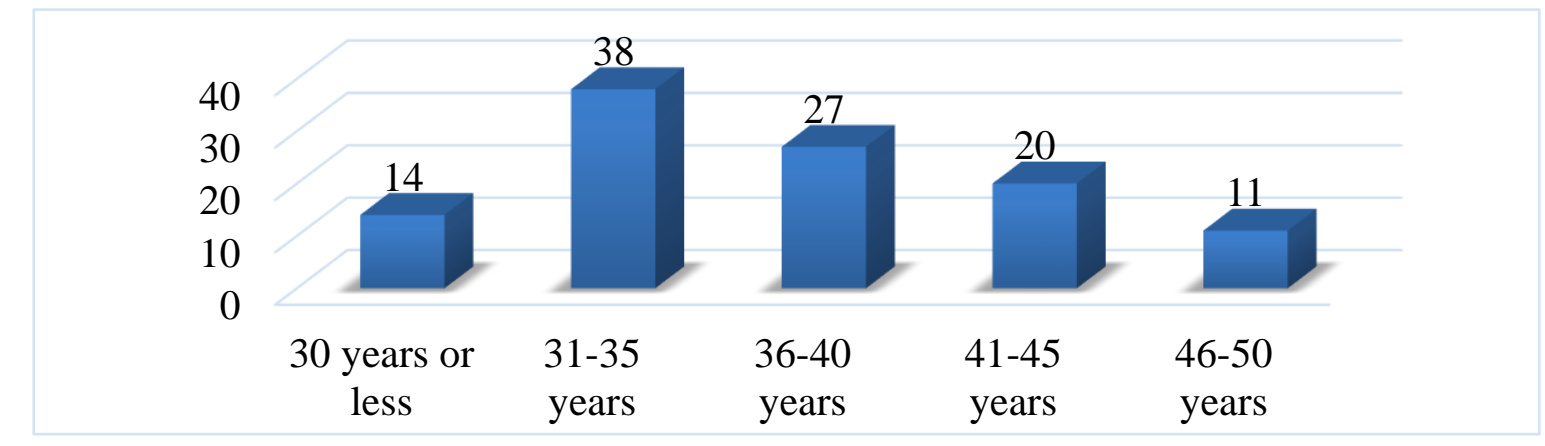

$\mathbf{N}=\mathbf{1 1 0}$

\section{Figure 2: Teachers' Age Distribution}

Thirty-eight (34.5\%) teachers were aged between 31 and 35 years, $27(24.5 \%)$ between 36 and 40 years, $20(18.2 \%)$ between 41 and 45 years, $14(12.7 \%)$ were aged 30 years or below, and $11(10.0 \%)$ were aged 46 years or more. The teachers' mean age was 37 years.

The teachers were also asked about their working experience - the number of years one had worked as a teacher. Figure 3 shows the findings.

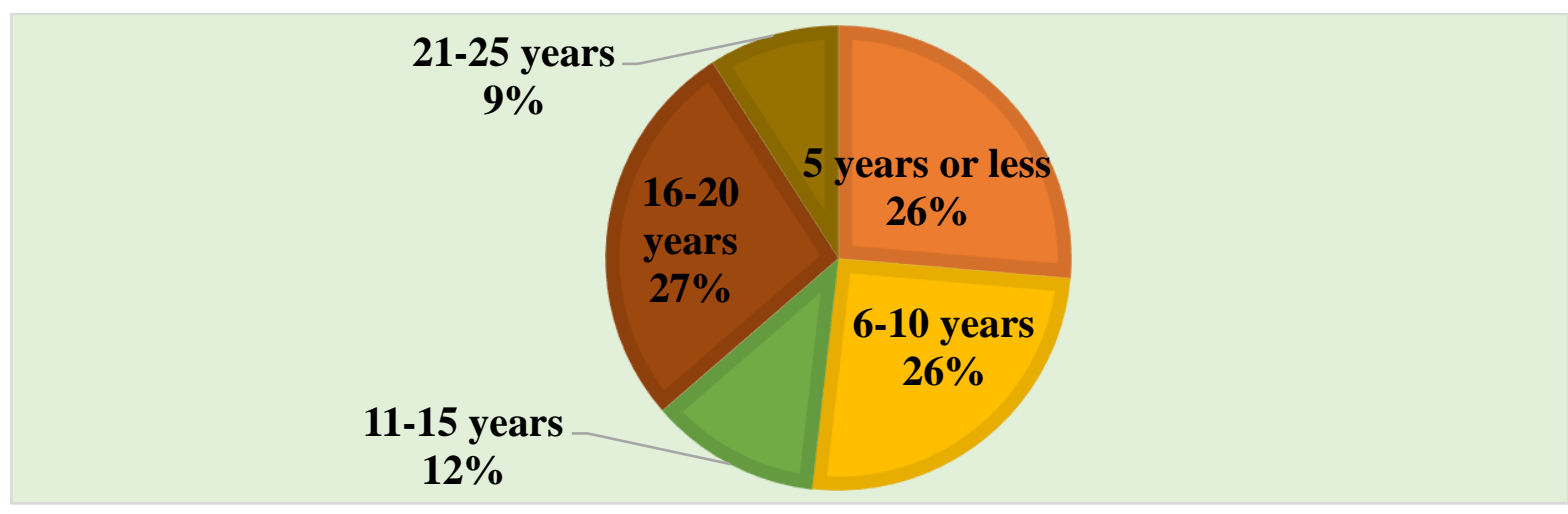

$\mathbf{N}=\mathbf{1 1 0}$

\section{Figure 3: Teachers' Working Experience}

Thirty (27.3\%) teachers had a teaching experience of between 16 and 20 years, $29(26.4 \%)$ had an experience of 5 years or less, $28(25.5 \%)$ had an experience of between 6 and 10 years, 13 (11.8\%) had an experience of between 11 and 15 years, while $10(9.1)$ had an experience of 21 or more years. The teachers' average working experience was 11 years. We can, therefore, conclude from Figure 2 and Figure 3 that most teachers $(71.8 \%)$, were aged 40 years and below, and most of them $(63.6 \%)$ had taught for 15 years or less. This group could be classified as 
Journal of Education and Practice

ISSN 2520-467X (online)

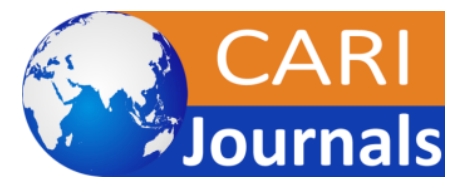

Vol.4, Issue No.3, pp $56-87,2020$

$\underline{\text { www.carijournals.org }}$

young professionally since most of them still had more than half of their teaching years ahead of them considering that in Kenya, the current retirement age from formal employment is 60 years. Their teaching experience could also be said to be fairly short, especially compared with that of the $10(9.1 \%)$ teachers who had a teaching experience of 21 years and above.

\section{Respondents' Length of Stay in their Present Schools}

This study also sought to establish the teachers' length of stay (in years) in their present schools. Figure 4 shows of the respondents' length of stay in their current schools.

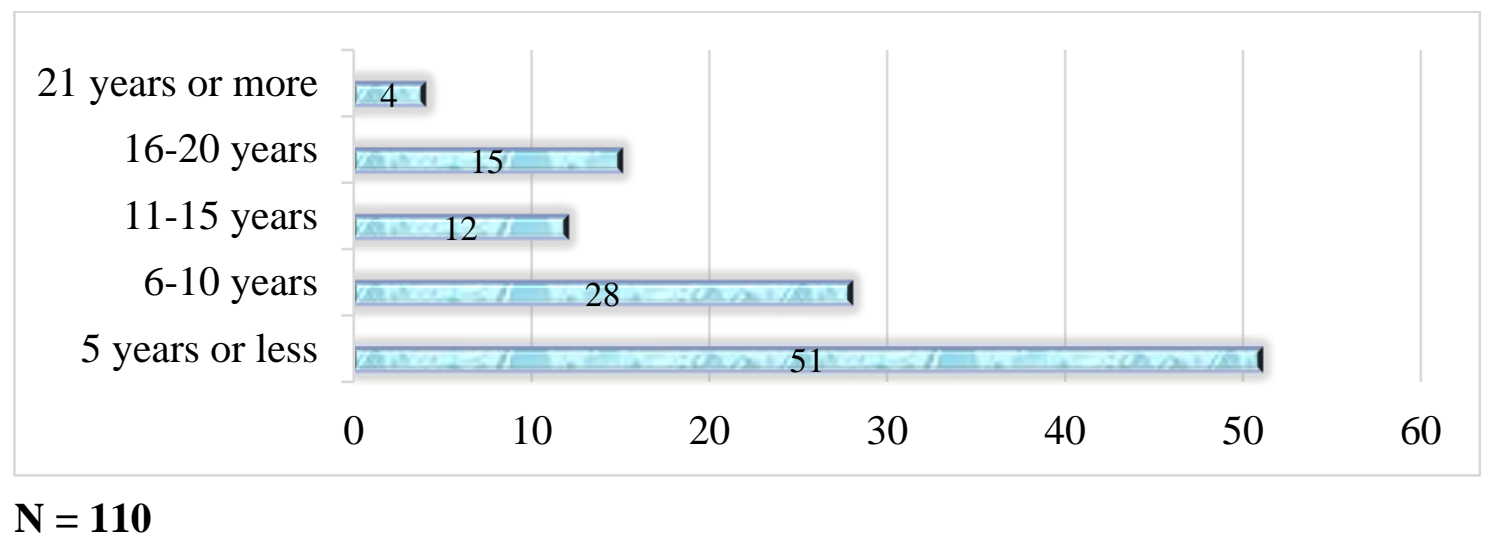

\section{Figure 4: Teachers' Length of Stay in Current Schools}

Fifty-one $(46.4 \%)$ teachers had been teaching in their current schools for 5 years or less, 28 $(25.5 \%)$ for between 6 and 10 years, 15 (13.6\%) for between 16 and 20 years, 12 (10.9\%) for between 11 and 15 years, and $4(3.6 \%)$ for 21 years or more. The teachers' mean length of working in their present stations was 8 years. Therefore, by the time of this study, most teachers - 59 (53.6\%) - had worked in the e-Schools for more than 6 years. Hence, they were either already working in the schools before the introduction of ICTs, during piloting, or shortly after the piloting period. This would lead one to expect that these teachers had been inducted in the use of the ICTs, and were therefore probably more skilled and experienced using them than the teachers who had taught in the e-Schools for 5 years or less.

It has been observed that teacher characteristics are important in any educational improvement or innovation (Fullan, 2001; Tang \& Ang, 2002). For instance, teachers' sex (or gender) can influence the adoption of a new idea (Rogers, 2003; Afshari et al., 2009). Differences in academic and professional qualifications can also contribute towards teachers' tendencies to differ in performance level, innovation, capacity and affinity to change (Schiller, 2003; Afshari et al., 2009). For teachers to productively integrate ICTs, they ought to be academically and professionally qualified to ensure that they know how to and the reasons for interweaving content, pedagogy and technology (Mishra \& Koehler, 2008; 2006).

However, age and professional experience have also been found to influence the adoption of an innovation (Rogers, 2003; Schiller, 2003; Afshari et al., 2009). Younger and newer teachers are viewed as more likely to use ICTs in their classes than their older colleagues due to, partly, the fact that new teachers may have been exposed to ICTs during their pre-service training than their predecessors (Afshari et al., 2009). Moreover, younger people are more open to new ideas even if they do not have prior knowledge. Older teachers, having successfully established routines that meet their standards of quality, hesitate to embrace change especially if they do not appreciate the rationale for change (Scott \& Usher, 2010). 
Journal of Education and Practice

ISSN 2520-467X (online)

Vol.4, Issue No.3, pp $56-87,2020$

$\underline{\text { www.carijournals.org }}$

\section{Respondents' ICTs Training Status}

The teachers were asked if they had been trained or in-serviced on the use of ICTs. Sixty-seven $(60.9 \%)$ said they had been trained, while $43(39.1 \%)$ teachers said they had not been trained. Figure 5 summarizes the teachers' training status by gender.

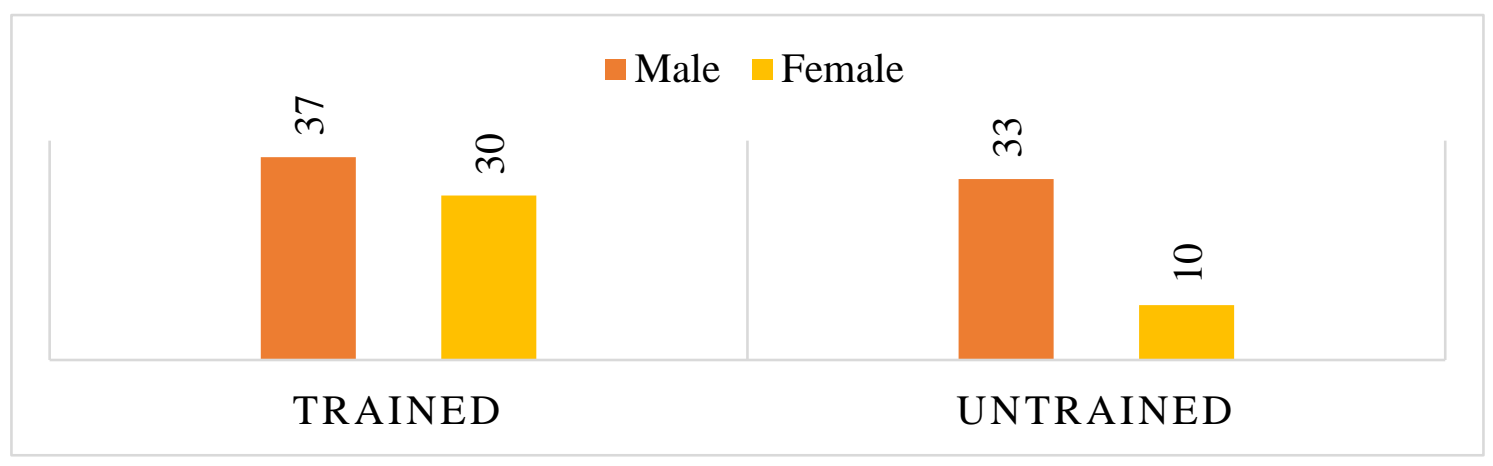

$\mathbf{N}=\mathbf{1 1 0}$

Figure 5: Teachers' training status by gender

Figure 5 shows that $37(55.2 \%)$ of the trained teachers were male and $30(44.8 \%)$ were female. This could lead one to hastily conclude that more males than females were trained and, hence, support many studies that assert that more male teachers' are usually trained, and influenced to adopt and use ICTs than their female counterparts (Rogers, 2003; Schiller, 2003; Afshari et al., 2009). However, the current study shows that the ratio of training per gender places female teachers ahead of males. Thirty $(75.0 \%)$ of the 40 female respondents had been trained, while $37(52.9 \%)$ of their 70 male counterparts had been trained. The explanation for this scenario was that most of the teachers who had not been trained (33 out of 43 or $76.7 \%$ ) were males, who had taught in the e-Schools for not more than 5 years. These teachers had either been freshly employed or had been transferred from schools outside the e-Schools programme. Hence, the current findings contrast assertions that the ratio of male teachers' that are usually trained in ICTs exceeds that of their female counterparts (Rogers, 2003; Schiller, 2003; Afshari et al., 2009).

The 43 teachers who had not been trained were asked to give reasons for their status. Thirtynine $(90.7 \%)$ said no training had occurred since they joined the schools, while $4(9.3 \%)$ said they had not been involved in the training sessions despite being in the schools during the training sessions. Therefore, the conclusion was that most of the untrained teachers joined their schools after the training sessions ended. Furthermore, what had been done in terms of length of training was what is termed as a 'one-off' training rather than extensive, on-going exposure to ICTs (Lau \& Sim, 2008 and Trucano, 2005). Moreover, the trained teachers did not cascade skills down to their untrained colleagues as had been hoped.

Scholars believe that, for teachers to enhance their integration skills, they should engage in both initial and on-going training activities in ICTs. Instead of conducting customary one-time training workshops and events, there should be on-going professional development and regular updates (Lau \& Sim, 2008; Boakye \& Banini, 2008 and Trucano, 2005). This is not only for quality professional training to help teachers implement ICTs and transform their teaching (Brinkerhoef, 2006; Lawless \& Pellegrino, 2007), but also to give opportunities for late entrants and new teachers to be trained. However, even if a teacher is not trained on integration of ICTs, the effect of teachers' on-job practical interactions with ICTs cannot be overlooked. The kind 
Journal of Education and Practice

ISSN 2520-467X (online)

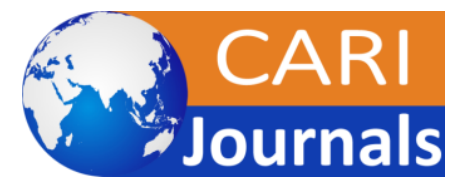

Vol.4, Issue No.3, pp 56 - 87, 2020

www.carijournals.org

(or quality) and length of experience with ICTs can influence tutors' adoption of ICTs for instructional use (Schiller, 2003; Afshari et al., 2009). Time plays a key role in ICTs adoption and integration. For example, the length of time a teacher takes from their first experience with ICTs through their adoption or rejection - compared with other teachers in the system - and the ICTs' rate of adoption into instruction (the number of teachers adopting and integrating ICTs in a given time span) form part of the determinants of the extent of integration of ICTs into instruction (Rogers, 2003).

\subsection{Adequacy of Resources for Integration of ICTs in Instruction}

Objective one of this study was: To determine the adequacy of the resources and infrastructure available in NEPAD e-Schools to support the integration of ICTs in instruction. Available resources are those devices, machines, equipment, tools, materials, programmes, conditions and/or infrastructure present in schools that would support the integration of ICTs. The main instrument used to generate this data was the Resources Checklist.

One of the basic criteria used by the government to select the NEPAD e-Schools from across the country was that they were accessible and having reliable supply of electricity (MoE, Kenya; 2008). Therefore, all the schools were accessible by road and had electricity supply from the Kenya Power Company. The status of the other ICT resources, infrastructure and systems expected and/or found in the selected schools are as summarized in Table 2 below.

Table 2: Status of Expected ICT Resources, Infrastructure and Systems

\begin{tabular}{lll}
\hline Components & Available & Functional \\
\hline Computer Laboratory & 7 & 7 \\
Multimedia centre & 5 & 4 \\
Servers & 6 & 3 \\
Desktop Computers & 241 & 180 \\
e-Content Applications & - & - \\
Smart Boards & 3 & 2 \\
Fully established LAN (Routers \& Access Points) & - & - \\
Fully established Internet connectivity and access & - & - \\
Television(-cum-radio) sets & 7 & 6 \\
Printers & 19 & 8 \\
Multi-functional Printers/Copiers/ Scanners/ Faxes & 9 & 5 \\
Projectors & 11 & 11 \\
DSTV & 6 & 4 \\
Stand-alone radio facilities & - & - \\
\hline
\end{tabular}

Each of the $5(100 \%)$ schools had at least one computer laboratory. Two (40\%) of them had 2 computer labs each, thus, increasing the total number of labs to 7 . All the labs were functional and accessible. Each school had a multimedia centre housed in the computer labs. All the multimedia centres were functional except one. All the multimedia centres were accessible. There was at least one server in each of the 5 schools. One school had added an extra server. However, the servers were functional only in two schools. All the servers were accessible. The schools had a total of 241 computers, all of which were accessible. However, 180 (75\%) were the ones that were functional at the time of the study.

Learn-things and e-contents were available in $4(80 \%)$ schools - obtained through different methods. Some of the contents had been downloaded earlier while the internet was functional 
Journal of Education and Practice

ISSN 2520-467X (online)

Vol.4, Issue No.3, pp $56-87,2020$

www.carijournals.org

and some were being accessed and downloaded using 3G/4G modems either availed to some teachers and students by the schools or that the teachers and students had bought themselves. The smart board was available in $3(60 \%)$ schools, with each having only one smart board. However, it was functional in only 2 schools. In all the 3 schools, the smart board was accessible. The fully established LAN (Routers and access) points were available in two (40\%) schools but they were no longer functional. However, they were accessible.

All $5(100 \%)$ schools had projectors - the average number per school being 2 . One school had 5 , another had 3 and three schools had 1 projector each. All the projectors were functional and accessible. In all $5(100 \%)$ schools, the originally provided fully established internet connectivity and access were no longer there. Hence, 2 (40\%) schools had installed their own internet connectivity, while in another $2(40 \%)$ students and teachers relied mainly on commercial $3 \mathrm{G} / 4 \mathrm{G}$ modems from telecommunication and internet service providers. One (20\%) school had abandoned internet altogether. All 5 (100\%) schools had printers at an average of almost 4 per school. However, out of a total of 19 printers available in the schools, only $8(42.1 \%)$ were functional; an average of less than 2 per school. All the printers were, however, accessible.

Nine multi-functional printers, copiers-scanners-faxing machines were available and accessible in the 5 schools, but only 5 (55.6\%) were functional. All the $5(100 \%)$ schools had television (TV) sets. Four schools had a TV set each, while one school had 3 sets. All the sets were functional except one, which again happened to be the only set in the school. All the sets were accessible. All the 5 (100\%) schools had DSTV equipment. Four schools had a set each, while one school had 2. However, 2 sets were not functional in 2 schools, despite being the only ones in the schools. All the equipment were accessible. None of the schools had any standalone radio equipment.

Based on the above findings, this study established that all the schools under investigation had functional and accessible electricity supply. However, in all cases, the supply was not reliable because schools were experiencing frequent power outages as witnessed by the researcher. This could bear on the functions and use of the ICTs since users could feel constrained by the outages. The study also established that the schools had tried to increase, improve on or maintain some of the project resources, infrastructure and systems while ensuring that they were also functional and accessible. For instance, all the schools had added several computers increasing the total tally from the initially supplied 115 to 241 . Three $(60 \%)$ of the schools had actually more than doubled (or even tripled) the number of computers. Yet, the data also reveals that the schools were contending with maintenance challenges; especially of computers, printers and servers. For instance, about $1 / 4(61)$ of the computers were not functioning or were obsolete, irreparable or outdated, translating to an average of at least 12 non-functional computers per school. As a result, the schools' populations were sharing the remaining functional 180 computers at an aggregate ratio of 26 users per computer; at least 24 of them being learners as depicted in Table 3. 
Journal of Education and Practice

ISSN 2520-467X (online)

Vol.4, Issue No.3, pp 56 - 87, 2020

$\underline{\text { www.carijournals.org }}$

Table 3: Aggregate Users of Computers per School

\begin{tabular}{|c|c|c|c|c|c|c|c|}
\hline \multirow[t]{2}{*}{ School } & \multicolumn{3}{|c|}{ Users of computers per school } & \multirow{2}{*}{$\begin{array}{l}\text { Total } \\
\text { Users }\end{array}$} & \multirow{2}{*}{$\begin{array}{l}\text { Functional } \\
\text { computers }\end{array}$} & \multirow{2}{*}{$\begin{array}{l}\text { Students } \\
/ \\
\text { compute } \\
\text { r }\end{array}$} & \multirow{2}{*}{$\begin{array}{l}\text { Users/ } \\
\text { compute } \\
\mathbf{r}\end{array}$} \\
\hline & $\begin{array}{l}\text { Principal } \\
\mathrm{s}\end{array}$ & $\begin{array}{l}\text { Teacher } \\
\mathrm{s}\end{array}$ & Students & & & & \\
\hline School 1 & 1 & 62 & 1065 & 1128 & 62 & 17.18 & 18.19 \\
\hline School 2 & 1 & 24 & 398 & 423 & 17 & 23.41 & 24.88 \\
\hline School 3 & 1 & 56 & 1017 & 1074 & 33 & 30.82 & 32.55 \\
\hline School 4 & 1 & 54 & 1003 & 1058 & 49 & 20.47 & 21.59 \\
\hline School 5 & 1 & 33 & 556 & 590 & 19 & 29.26 & 31.05 \\
\hline Totals & 5 & 229 & 4039 & 4273 & 180 & 121.14 & 128.26 \\
\hline Mean & 1.00 & 45.80 & 807.80 & 854.60 & 36.00 & 24.23 & 25.65 \\
\hline Std. & .000 & 16.377 & 307.961 & 324.248 & 19.391 & 5.772 & 6.111 \\
\hline Dev. & .000 & 268.200 & 94839.70 & 105136. & 376.000 & 33.310 & 37.348 \\
\hline Varianc & 0 & 38 & 0 & 800 & 45 & 14 & 14 \\
\hline & & & 667 & 705 & & & \\
\hline Range & & & & & & & \\
\hline
\end{tabular}

(Source: NEPAD e-Schools, Kenya; 2012)

The findings of this study are consistent with those of other ICTs integration studies previous studies done in Kenya by, among others, the Kenya SchoolNet (2003), Ndiku (2003), Begi (2007) and Mugo (2007) that showed large school populations sharing a few functional computers and other ICTs. For instance, Mugo (2007) observed that the NEPAD ICTs were too few for the large number of students; the computers to students ratio being 1:25. This signifies a huge need for schools and other parties engaging in ICTs integration to be ready to invest a lot in acquiring and maintaining computers and other ICTs if they desire to attain standards that are comparable to those being witnessed by schools in the developed world. For instance, a study by Statistics Canada (2012) showed that the average computer to learners ratio was about 1:1.8 among 15 year old students in the developed countries, with some having attained national average ratios of 1 student per computer by the year 2009. In the USA, findings by the National Center for Education Statistics (2010) showed that by 2009, the highest ratio of students to computers in the everyday classroom was 5.3 to 1 , and some schools had more computers than students.

The findings of the current study are also congruent with Mungai's (2011) assertion that even though a good number of schools in Kenya have benefited from donated computers, they have not been adequately capacitated on necessary maintenance and repair, making it very common to see schools' computer labs full of broken down computers, repairable or otherwise. This ups competition among users and lowers overall access. The current study, however, seems to contrast drastically the assertion by Kiptalam and Rodrigues (2010) that access to ICT facilities is a major challenge facing Kenya and most African countries, with a ratio of one computer to 150 students; but seems to concur with Wims and Lawler's (2007) findings that some schools and colleges in Kenya have better ratios of students to computers. Yet, the current findings compare poorly against the average ratio of 1:15 students in developed countries where some countries, especially members of the Organization for Economic Co-operation and Development (OECD) - or G8, had almost attained national mean ratios of 1 student per computer by 2009 (Statistics Canada, 2012). 
Journal of Education and Practice

ISSN 2520-467X (online)

Vol.4, Issue No.3, pp $56-87,2020$

$\underline{\text { www.carijournals.org }}$

It is also clear from the current study that other resources, infrastructure and systems had also been variously increased, improved on, maintained or downgraded by each individual school. For instance, computer labs, multimedia centres and systems, servers, learn-things and econtents, smart boards, projectors, printers, multi-functional printing-copying-scanning-faxing machines, television sets and DSTV equipment had been increased, improved on, maintained or downgraded to different degrees by each school (see Table 1). However, some resources, infrastructure and systems had either been replaced or completely lost in virtually all the schools. In particular, all the schools had lost the initial fully established internet connectivity and access, and had either sought for alternative means or abandoned the internet altogether.

This could help explain why some schools were lacking or had limited learn-things and econtents. In particular, the learn-things and e-contents were available in four schools which had been or could be obtained through different methods depending on each school. Some of the contents had been downloaded earlier while the system was functional and some were being accessed and downloaded using a few $3 \mathrm{G} / 4 \mathrm{G}$ modems either availed to some teachers and students by the schools or that the teachers and students had bought themselves.

The findings of the current study are congruent with Farrell and Isaacs' (2007) and Castells' (2000) assertion that some of the major constraints ICTs' use in schools in Africa are inconsistent or unavailable supply of electricity, insufficient, unavailable and/or inaccessible ICT equipment and infrastructure, overcrowding of computer labs, and lack of affordable access to connectivity with acceptable bandwidth. This inhibits the use of ICTs to even provide basic access to digital information. Hence, to guarantee a predictable transition to electronic networks, African (and Kenyan) schools must first get reliable basic infrastructure and internet connectivity, and consistent electricity supply, which still widely lacks. For instance, in a study among Ugandan secondary schools, Ndawula, et al. (2013) also established that most rural schools and homes suffer from power shortage. This cripples operation of ICTs, prompting Osakwe (2010) to urge for a steady power supply for them to be effective.

The general consistency of the finding of this study with other related studies in Africa and Kenya in particular should prompt the government, schools and other parties involved in ICTs in education to try and come up with long-term strategies of re-equipping schools, while ensuring that those resources already available in schools continue to be well maintained. The current study has demonstrated that even though schools may endeavour on their own to provide, add or maintain ICTs, in some cases they may be overwhelmed, hence, requiring external support. Technical support in particular is consistently needed in these schools to guarantee continued maintenance and functionality of ICTs if the integration process is to succeed.

\subsection{Teachers' Frequency of Integration of ICTs into the Instructional Processes}

Objective two of the study was: To establish teachers' frequency of integrating ICTs into the instructional process. Frequency of integrating ICTs in this case refers to how often ICTs were being applied in teaching and learning. The main instrument used to generate this data was the Teachers' Questionnaire. The teachers were asked to state how often they were using ICTs in their teaching. One hundred teachers responded as summarized in Figure 6. 


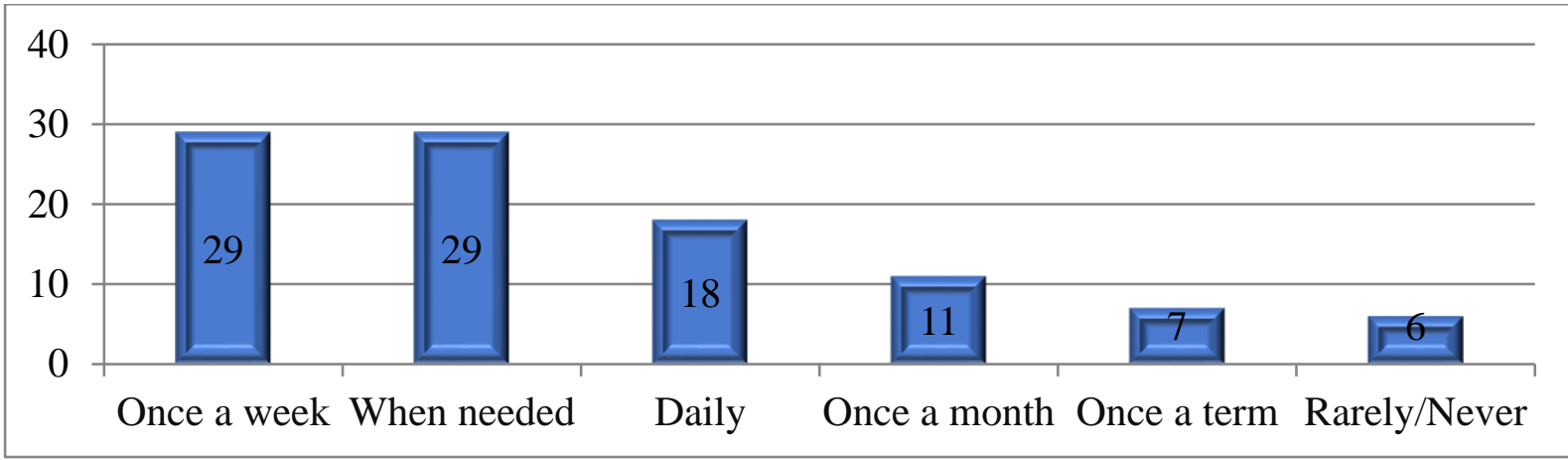

$\mathbf{N}=\mathbf{1 0 0}$

\section{Figure 6: Teachers' Frequency of Usage of the NEPAD ICTs in Teaching}

The frequency of integration of ICTs into instruction varied among teachers. However, overall, more teachers $(53.0 \%)$ infrequently, rarely, never or could not say how often they were integrating the ICTs than those teachers $(47.0 \%)$ who did so at least once a week, every day or during every lesson. This was more so because it was not possible to exactly quantify the 'whenever there was need' category since the need could vary from within a few lessons to rarely or never being there. Nevertheless, on a scale 1 (every day/lesson) to 6 (rarely/never), the mean frequency of use of ICTs by teachers in teaching was 3 (at least once a month) with a standard deviation of 1.666 and a variance of 2.775 . This calls for a resolute effort by all parties engaged in ICTs integration to ensure that teachers are sufficiently equipped and motivated to implement the ICTs integration programmes more frequently.

The above findings corroborate those by Begi (2007), Wims \& Lawler (2007) and Mugo (2007) that ICTs are less often used in classroom instruction except when teaching Computer Studies but contrast those by Kiptalam \& Rodrigues (2010) who established that the use of instructional ICTs and their integration in secondary education is becoming more widespread. The findings of the current study also generally echo assertions that despite the general increase in ICTs use world over in the recent years, their actual integration into the instructional processes is still poor (Cox, et al., 2004; Waxman, et al., 2002; Tearle, 2004).

Lee (2002) also noted that despite changes in society, formal classroom teaching is still driven by traditional teaching practices. Teachers are still widely referring to textbooks and acting as information givers because they fear taking risks. Hence, integrating ICTs in instruction is still a complex process of educational change, and the extent of ICTs application in schools is extremely varied and, sometimes, limited (Kirschner \& Selinger, 2003; Loveless \& Dore, 2002; Scrimshaw, 2004). Only a few teachers have meaningfully integrated ICTs and are using them to make significant changes in the classroom (Kirschner \& Selinger, 2003; Kozma, 2003; Smeets, 2005).

\subsection{Teachers' ICTs Preferences and Uses during Instruction}

Objective three of the study was: To establish the ICTs that are mostly preferred and used by teachers during instruction. The main instrument used to generate this data was the Teachers' Questionnaire. Hence, the teachers were asked to state the ICT resources and applications (hardware and software) that they preferred using more often than others in their teaching. Ninety-two teachers answered and their responses are summarized in Table 4. 
Journal of Education and Practice

ISSN 2520-467X (online)

Vol.4, Issue No.3, pp 56-87, 2020

www.carijournals.org

Table 4: ICTs Teachers Preferred More than Others

\begin{tabular}{lll}
\hline Resources/Applications & Frequency & Percent \\
\hline Desktop computers & 77 & 83.7 \\
LCD Projectors & 45 & 48.9 \\
PowerPoint slides & 55 & 59.8 \\
Printers/print matter & 47 & 51.1 \\
Internet & 50 & 54.3 \\
Ms Word/word processing & 58 & 63.0 \\
Ms Excel/Spreadsheets & 31 & 33.7 \\
Smart board & 31 & 33.7 \\
Animations & 30 & 32.6 \\
Television & 48 & 52.2 \\
DVD player/DVDs/VCDs & 43 & 46.7 \\
Encarta Library & 43 & 46.7 \\
\hline
\end{tabular}

Multiple responses $(\mathrm{N}=92)$

Seventy-seven teachers $(83.7 \%)$ preferred using the desktop computers, $58(63.0 \%)$ preferred word processing using Microsoft Word, 55 (59.8\%) preferred preparing and using PowerPoint slides, $50(54.3 \%)$ preferred the Internet, and $48(52.2 \%)$ preferred using the television. Fortyseven $(51.1 \%)$ preferred using printers and print matter, $45(48.9 \%)$ preferred the LCD projectors, 43 (46.7\%) preferred DVD players, DVDs and VCDs, and $43(46.7 \%)$ preferred the Encarta Library application among their other responses. Most respondents gave multiple responses. Therefore, the teachers' most preferred ICT resources (or hardware) were desktop computers, while their most preferred ICT application (or software) was word processing using Microsoft Word.

The teachers were then asked to indicate the main uses of the ICTs during their lessons. Eightynine teachers responded and Table 5 below presents a summary of their responses.

Table 5: Teachers' Main Uses of ICTs

\begin{tabular}{lll}
\hline Main uses of ICTs to teach & Frequency & Percent \\
\hline Illustrating main points & 55 & 61.8 \\
Giving assignments & 7 & 7.9 \\
Marginal teaching aids/ rarely used & 12 & 13.5 \\
Illustrating main points \& giving assignments & 7 & 7.9 \\
Main content sources \& illustrating main points & 8 & 9.0 \\
Total & 89 & 100.0 \\
\hline
\end{tabular}

Fifty-five teachers $(61.8 \%)$ were using them to illustrate the main points/ideas during their lessons, $12(13.5 \%)$ were using them as marginal teaching aids (rarely used), while $8(9.0 \%)$ were using them to illustrate major ideas during lessons and as the main sources of instructional content. Seven (7.9\%) were using them to give learners assignments, and a similar number were using them to illustrate main points and to give learners assignments. The findings of the study, therefore, revealed that majority of the teachers were mainly using the ICTs to illustrate the main points/ideas during their lessons.

These findings agree with those of the Robert Gordon University Aberdeen (2004) who, in a study conducted in Scotland on teachers' ICT skills and knowledge, reported that the use of ICTs is relatively low and is focused on a fairly narrow range of ICTs. Word processing was 
Journal of Education and Practice

ISSN 2520-467X (online)

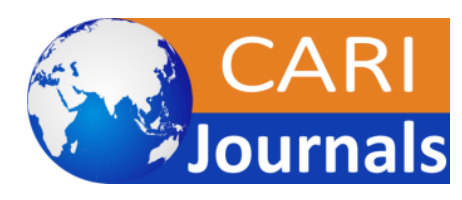

Vol.4, Issue No.3, pp $56-87,2020$

www.carijournals.org

the predominant use made of ICTs in schools. There was some use of externally produced educational software but secondary teachers tended to use a wider range of generic packages such as spreadsheets and DTP (Desktop Publishing) than did primary teachers. There was very little use of the Internet and WWW (World Wide Web) or e-mail by teachers, even though majority of secondary schools had access to the Internet. Resources like video conferencing and network computer conferencing were rarely used.

That study further revealed that secondary teachers used ICTs as much or more for professional development and personal use as in the classroom. Teachers were using ICTs across the curriculum but use and attitude varied in secondary schools between subjects. Mathematics and science teachers were using ICTs relatively little while, amongst non-computing teachers, ICTs were being used most by teachers of business and management subjects. The current study, however, did not delve into establishing the variations in the use of ICTs across the curriculum.

Teachers in the current study, then, stated the factors that they consider when selecting and using the ICTs in their teaching. Eighty-seven teachers responded as indicated in Table 6.

Table 6: Factors influencing teachers' selection and use of ICTs in Teaching

\begin{tabular}{lcc}
\hline Influencing factor & Frequency & Percent \\
\hline Number of students/class enrolment & 19 & 21.8 \\
Time constraints for preparation and use & 37 & 42.5 \\
Lesson objectives & 32 & 36.8 \\
Resource (ICTs) availability and accessibility & 35 & 40.2 \\
Nature of subject content/topic & 48 & 55.2 \\
Level and characteristics of learners & 39 & 44.8 \\
Learner preferences & 16 & 18.4 \\
Relevance of ICTs to content & 38 & 43.7 \\
Clarity of the ICTs & 26 & 29.9 \\
Efficiency and ease of use of ICTs & 33 & 37.9 \\
Electricity supply & 14 & 16.1 \\
\hline
\end{tabular}

Multiple responses $(\mathrm{N}=87)$

Forty-eight (55.2\%) teachers considered the nature of subject content and topic being taught, $39(44.8 \%)$ considered the level and characteristics of the learners, $38(43.7 \%)$ considered the relevance of the ICTs to content being taught, and $37(42.5 \%)$ considered time constraints in the preparation and use of the ICTs. Thirty-five (40.2\%) considered the ICTs' availability and accessibility, 33 (37.9\%) considered the efficiency and ease of use of the ICTs especially for the learners, while 32 (36.8\%) considered the lesson objectives among other considerations. Most of the respondents gave multiple responses.

Therefore, the findings of this study reveal that teachers considered a number of factors when selecting and using ICTs in their teaching, the most important being the nature of subject content and topic being taught. This is, perhaps, because different subject areas, subject contents and topics require different methods and approaches to teaching which, in turn, dictate the use of different instructional resources. However, the importance of the other factors cannot be gainsaid. A consideration of each one of them enables the teacher to arrive at the most appropriate resources to use in a particular context.

These findings lend credence to Mishra \& Koehler's (2008) assertion that successful integration of ICTs in education is driven by a composite interrelationship among the different 
Journal of Education and Practice

ISSN 2520-467X (online)

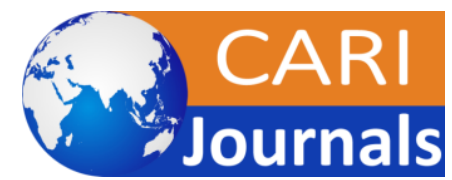

Vol.4, Issue No.3, pp $56-87,2020$

www.carijournals.org

elements, which are contextually bound. Teachers' content knowledge plays a crucial role in determining how they eventually integrate ICTs into instruction. However, content knowledge is not enough. The necessary pedagogical training (knowledge), whatever technologies available and accessible in schools and the teachers' own abilities to integrate new technologies into instruction (technological knowledge) can also strongly influence how teachers eventually integrate ICTs into instruction (Mishra \& Koehler, 2008). Components of the above elements vis-à-vis the school contexts and instructional settings could also be revealed by this study.

The teachers were then asked to say how easy it was for them to use ICTs in their teaching. Ninety-three teachers responded as indicated in Figure 7 below.

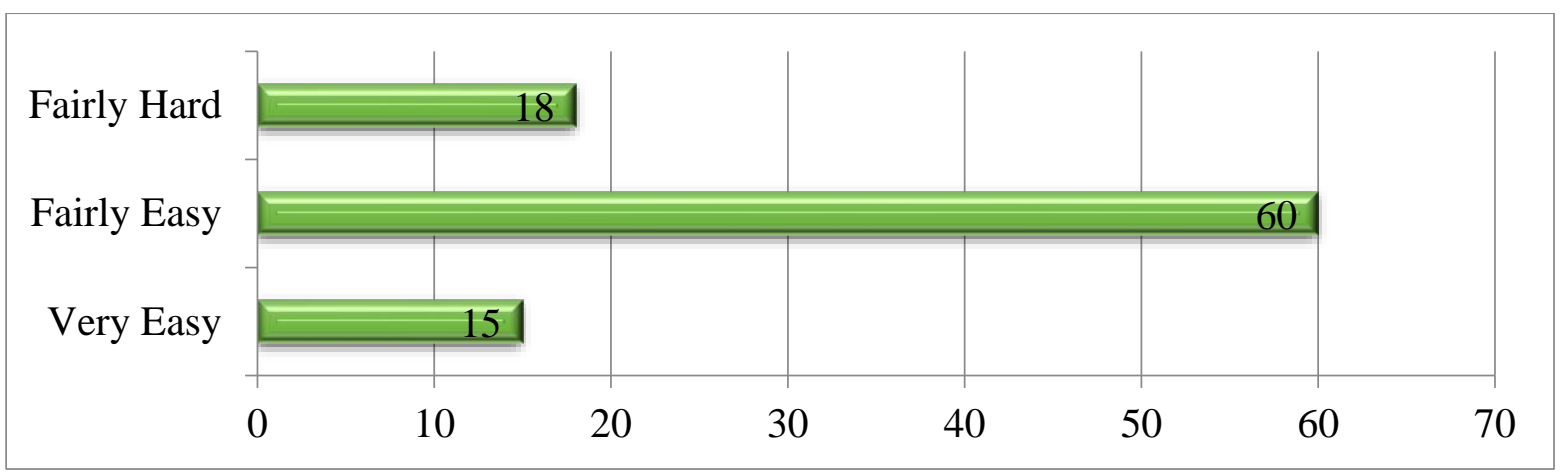

$\mathbf{N}=93$

\section{Figure 7: Ease of Use of ICTs in Teaching by Teachers}

Sixty $(64.5 \%)$ teachers said it was fairly easy, 18 (19.4\%) said fairly hard, and $15(16.1 \%)$ said it was very easy to use ICTs in their teaching. Therefore, most teachers $(80.6 \%)$ had found the use of ICTs in their teaching to be generally easy. The above findings echo earlier assertions that teachers are becoming increasingly at ease with using ICTs in their duties. For instance, studies done by Lau \& Sim (2008) and Kiptalam \& Rodrigues (2010) established that the use of ICTs for communication and information searching and their integration in teaching and learning was becoming more prevalent among teachers as they were becoming more skilled and comfortable working with ICTs. The current findings also agree with assertions by Davis et al. (1989) and Davis (1989) that a person adopts and uses a given system based on its ability to enhance one's job performance or efficiency, and/or its ease of use. Hence, ICTs must be easy to teachers for them adopt and use (Roblyer, 2006). Some need to see others using ICTs to be assured that they too can. The experiences of earlier users influence those that are yet to try (Rogers, 2003). They need to be reassured that ICTs are working, easy to use and are yielding expected results.

\subsection{Teachers' Practical Applications of ICTs in Instruction}

Objective four of the study was: To discover teachers' practical application of ICTs in instruction. In order to learn how teachers practically integrate ICTs in teaching, classroom observations were conducted during the teachers' form three lessons. This would also enable the researcher to ascertain the types of ICTs being used, the extent to which they are used, and their relevance to the instructional process. The instrument used to generate this data was the classroom observation guide. All the 110 form three teachers were observed while teaching in two lessons each. The aspects featured during the observations were whether teachers had lesson plans, the ICTs the teachers had during the lessons, the ICTs actually used, teachers' 
Journal of Education and Practice

ISSN 2520-467X (online)

Vol.4, Issue No.3, pp $56-87,2020$

www.carijournals.org

proficiency levels in using the ICTs, how the teachers used the ICTs during the lesson, how the teachers organized students while using the ICTs, how the students were using the ICTs, relevance of the ICTs to the topics being taught, among other issues.

All the 110 (100\%) observed teachers had lesson plans during their lessons. This meant that all lessons were planned. During observations, 100 (90.9\%) teachers conducted their lessons in the computer-cum-media labs. That was where the ICTs were kept, some of them immovable or cumbersome to move around or to bring to class. The classroom setting could also not cater for some of the ICTs (e.g. the smart board). Only 10 teachers $(9.1 \%)$ conducted both their lessons in the classroom. This therefore meant that $100(90.9 \%)$ teachers had ICTs at their disposal during their lessons, while $10(9.1 \%)$ did not. Of the 100 teachers who had ICTs at their disposal, $55(55.0 \%)$ had computers and LCD projectors during their lessons, while 45 $(45.0 \%)$ had computer, projectors and smart board. The available ICTs also depended on the school. All the 5 schools had computers and projectors but only two had functional smart boards (see Table 2).

During their both lessons, 63\% of the 100 teachers that had ICTs at their disposal used computers and LCD projectors, 34\% used computers, LCD projectors and smart boards, $1 \%$ used computers only, another $1 \%$ used the smart board and the teacher's computer only, while $1 \%$ did not use any ICTs even though they were at their disposal. Most teachers (99\%), therefore, who had ICTs at their disposal, used at least computers in their teaching, where 98\% either combined them with LCD projectors, smart board or both.

During the lessons, the 100 teachers who had ICTs at their disposal exuded different levels of proficiency in using the ICTs while teaching where $47 \%$ were above average, $31 \%$ were average, while $11 \%$ were very skilled/proficient. Another $10 \%$ used the ICTs but demonstrated very little skill or proficiency, while $1 \%$ did not use the ICTs. Most (58\%) teachers, therefore, were at least above average in proficiency in using ICTs in teaching.

The way the 100 teachers who had ICTs at their disposal used them varied slightly during the two observations. In the first observations, $50 \%$ used the ICTs to illustrate the major points of the lessons while in the second lessons, $51 \%$ used them for that purpose. In the first observations also, $28 \%$ used the ICTs to give assignments and/or engage learners in some learning activities, while in the second lessons $27 \%$ used them for the said purposes. However, during both lessons $21 \%$ of the teachers used the ICTs as marginal teaching aids, while $1 \%$ did not use the ICTs in either lesson. Therefore, the teachers used ICTs variously but more often (at least 50\%) to illustrate the major points of lessons.

The way the 100 teachers organized their students during the two lessons did not vary. In both lessons, $72 \%$ taught learners together as a whole class while using the ICTs, 14\% taught them as small groups of between 2-4 members each or depending on the available computers, while $13 \%$ gave them individual assignments or learning tasks. One (1\%) teacher did not use any of the available ICTs while teaching. In most lessons, therefore, learners learnt together as a whole class while using the ICTs.

The way the students interacted with the ICTs varied slightly during the two observations. In the first observations, $50 \%$ of the lessons involved students using the ICTs in observing teachers' presentations, $22 \%$ involved students using them only as marginal learning aids, $14 \%$ involved students using them actively in group assignments or learning activities, $7 \%$ involved 
Journal of Education and Practice

ISSN 2520-467X (online)

Vol.4, Issue No.3, pp $56-87,2020$

www.carijournals.org

students in individualized instructional activities, and $6 \%$ had learners engaging in hands-on practice activities. One (1\%) teacher did not use any of the ICTs present while teaching.

During the second observations, $51 \%$ of the lessons involved learners observing what was being presented by the teachers, $21 \%$ involved engaging students in the use of ICTs as marginal aids to learning (rarely used), 14\% involved engaging the learners in groups assignment/learning activities using ICTs, $8 \%$ involved engaging learners in hands-on practice activities, while 5\% involved engaging learners in individualized instructional activities. One $(1 \%)$ teacher did not use any of the available ICTs while teaching. Hence, despite variance in the way students interacted with the ICTs during lessons, the main interaction (at least 50\%) was via observation of teachers' presentations.

In both the first and second lesson series, the relevance of the ICTs used to the lessons or topics being taught by the 100 teachers who had them at their disposal was gauged. In both cases $89 \%$ were very relevant, $10 \%$ were fairly relevant, while $1 \%$ did not involve the use of ICTs. Hence, in both lesson series, most of the ICTs used were very relevant to the lessons or topics being taught. This implies that most teachers, regardless of their demographic characteristics, were able to select and use appropriately relevant ICTs during their respective lessons.

These observations concur with the U.S. Department of Education, National Center for Education Statistics' (2010) report that, apart from computers, projectors - LCD (liquid crystal display) or DLP (digital light processing), and interactive whiteboards (or smart boards) were the ICTs either available as needed or in the classroom every day and were being used for instruction. For the current study, however the devices were in the computer labs-cummultimedia centres.

The fact that most ICTs in the schools under study were being housed at, and could only be used in, the computer lab-cum-multimedia centre could have implications on access and, hence, frequency of integration of these tools in instruction. Since only one class or lesson could be accommodated at any given time, teachers and learners could either compete for the ICTs or feel disenfranchised altogether. Even if some ICTs could be portable, it was evident that the classrooms and other possible learning locations had not been designed to cater for them. This scenario is not unique to Kenya or this study. Other developing countries have had similar experiences. For instance, Hinostroza et al. (2005) observed that majority of the computers in Chilean schools were located in the computer labs mainly due to the nation's ICTs in Education policy. This rarely provides schools the leeway of installing or using ICTs in the classrooms.

This contrasts sharply with classrooms in the developed nations. According to the U.S. Department of Education, National Center for Education Statistics (2010), in the USA for instance, by 2009 , at least $97 \%$ of teachers had one or more computers located in the classroom every day, while $54 \%$ could bring computers into the classroom. Internet access was available for $93 \%$ of the computers located in the classroom every day and for $96 \%$ of the computers that could be brought into the classroom. The ratio of students to computers in the classroom every day was 5.3 to 1 . Teachers reported that they or their students used computers in the classroom during instructional time often $(40 \%)$ or sometimes $(29 \%)$. Teachers reported that they or their students used computers in other locations in the school during instruction often $(29 \%)$ or sometimes $(43 \%)$.

Yet, the findings of this study echo Lee's (2002) view that despite changes in society, formal classroom teaching is still driven by traditional teaching habits. Teachers still widely refer 
Journal of Education and Practice

ISSN 2520-467X (online)

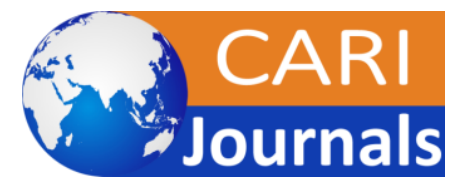

Vol.4, Issue No.3, pp $56-87,2020$

$\underline{\text { www.carijournals.org }}$

students to textbooks, and act as information givers because they fear taking risks. Despite the general increase in ICTs use world over in recent years, their actual integration in instruction has been poor (Cox, et al., 2004; Waxman, et al., 2002; Tearle, 2004). Integrating ICTs into instruction is still a complex process of educational change, and the extent of ICTs application in many countries and schools is extremely varied and, sometimes, very limited (Kirschner \& Selinger, 2003; Loveless \& Dore, 2002; Scrimshaw, 2004). Moreover, significant differences exist in the way ICTs are used in classrooms and schools (Goodison, 2002; O'Dwyer, et al., 2004).

Only a few teachers have integrated ICTs and use them to significantly impact their classrooms (Kirschner \& Selinger, 2003; Kozma, 2003; Smeets, 2005). In Africa, in particular, the general feeling is that the overall routine of teachers has not changed because their profession has not been influenced much by modern ICTs (Evoh, 2009a). One of the major challenges of educational change identified in Africa that affect the integration of ICTs into education is the poor quality of the teaching force (Evoh, 2009b). However, different studies (Ertmer, 1999; Mishra \& Koehler, 2006; Boakye \& Banini, 2008; Evoh, 2009b) have recognized several other forms of integration barriers facing ICTs in the school system (from personal fears among teachers, technical and logistical issues, to organizational and pedagogical concerns among others) that may lead to wrong application of ICTs and bring disservice to the education system.

\subsection{SUMMARY, CONCLUSIONS AND RECOMMENDATIONS}

\subsection{Summary of the Study Findings}

The summary of findings presented in this section is based on the objectives of the study.

\section{Adequacy of Resources for Integration of ICTs in Instruction}

All schools under investigation had functional and accessible electricity supply, but the supply was not reliable since all the schools were experiencing frequent power outages. The e-Schools had tried to increase, improve on, maintain or even downgrade to different degrees, some of the project resources, infrastructure and systems while ensuring that they continued to be functional and accessible. In particular, the e-Schools had increased the number of computers from the initial 115 to 241 . However, the schools were facing ICTs maintenance challenges; especially of computers, printers and servers. For instance, an average of at least 12 computers per school were not functioning, or were obsolete, irreparable or outdated. Therefore, users were sharing the functional computers at a rate of 26 users per computer; at least 24 of them being learners. Some resources, infrastructure and systems had either been replaced or completely lost (mainly internet).

\section{Teachers' Frequency of Integration of ICTs into the Instructional Processes}

More teachers infrequently, rarely, never or could not say how often they were integrating the ICTs than those who did so at least once a week, every day or during every lesson. Nevertheless, on average, the frequency of use of ICTs by teachers in teaching was at least once a month. 
Journal of Education and Practice

ISSN 2520-467X (online)

Vol.4, Issue No.3, pp $56-87,2020$

www.carijournals.org

\section{Teachers' ICTs Preferences and Uses during Instruction}

The most preferred ICT resources (hardware) among teachers were desktop computers, while the most preferred ICT application (software) was word processing using Microsoft Word. Majority of the teachers were mainly using ICTs to illustrate the main points/ideas during their lessons. When selecting and using ICTs in teaching, teachers considered a number of factors, the most important being the nature of subject content and topic being taught. Most teachers found the use of ICTs in teaching to be generally easy.

\section{Teachers' Practical Applications of ICTs in Instruction}

The ICTs that teachers would require during instruction were located in the computer labscum-multimedia centres. As a result, virtually all lessons involving integration of ICTs were being conducted there for teachers to access and integrate the ICTs. Most teachers (99\%), who had the ICTs at their disposal, used at least computers in their teaching, where $98 \%$ either combined them with LCD projectors, smart board or both. Most teachers had at least above average proficiency in using the ICTs while teaching. More often (at least 50\%), teachers were using ICTs to illustrate the major points of lessons. In most lessons, the teachers were teaching learners together as one group of the whole class. Moreover, students interacted with the ICTs during lessons mainly (at least 50\%) by observing teachers' presentations. Nevertheless, most $(89 \%)$ of the ICTs being used during lessons were very relevant to the lessons or topics being taught; an indicator of teachers' ability to apply their technological, pedagogical and content knowledge appropriately.

\subsection{Conclusions and Implications of the Study Findings}

In the light of the findings of this study, the following conclusions were drawn:

i) There is an enormous need for schools and other partners engaging in ICTs integration programmes to purposely invest in acquisition and maintenance of computers and other ICTs if they desire to attain standards comparable to those being witnessed by schools and programmes in the more developed parts of the world.

ii) Teachers and learners are constrained from interacting with and using ICTs more frequently and variously because of access. Location of resources at only one central place (the computer lab) is restrictive and therefore alienating to some. Therefore, there is need to designate more places if teachers and learners are to feel unimpeded and invited to use and integrate ICTs.

\subsection{Recommendations}

Based on the findings of this study, the following recommendations are made:

i) Schools with ICTs should have reliable, functional and accessible alternative sources of electricity to cater for power outages. Schools should also device means (like fundraisings, donations, fees and levies) to ensure provision and maintenance of sufficient ICTs to cater for their populations and to reduce ratios of ICTs to users to more manageable proportions.

ii) Schools should be more empowered in handling ICTs inventories. The government should assist public schools in sourcing for affordable spare parts as well as regular repair, maintenance and update services. The government should also provide the schools with avenues for disposing of obsolete, irreparable ICTs and e-waste management. 
Journal of Education and Practice

ISSN 2520-467X (online)

Vol.4, Issue No.3, pp 56 - 87, 2020

www.carijournals.org

\section{REFERENCES}

Afshari, M., Abu Bakar, K., Su Luan, W., Abu Samah, B. \& Say Fooi, F. (2009). Factors Affecting Teachers' Use of Information and Communication Technology. International Journal of Instruction. Vol. 2(1):77-104.

Ajzen, I., \& Fishbein, M. (1980). Understanding Attitudes and Predicting Social Behaviour. Englewood Cliffs, NJ: Prentice-Hall.

Al-Alwani, A. (2005). "Barriers to Integrating Information Technology in Saudi Arabia Science Education." Doctoral dissertation, the University of Kansas, Kansas.

Ayere, M. A.; Odera, F. Y. \& Agak, J. O. (2010). A Comparison of Information and Communication Technology Application in New Partnership for Africa's Development (NEPAD) and Non-NEPAD Schools in Kenya. Journal for Information Technology Education, Vol. 9 pp. 249-267. Available online at: www.jite.org/documents/vol9/JITEv9p249-267Ayere 748.pdf

Balanskat, A., Blamire, R., \& Kefala, S. (2006). A review of studies of ICT impact on schools in Europe. European Schoolnet.

Becta (2008). How do boys and girls differ in their use of ICT? Research report. Available online: http://dera.ioe.ac.uk/8318/1/gender_ict_briefing.pdf

Becta (2004). A Review of the research literature on barriers to the uptake of ICT by teachers. Retrieved August 13, 2008, from: http://www.becta.org.uk

Begi, N. (2007). “A Comparative Study of Pre-primary and Lower Primary School Teachers' Computer Technology Usage in Teaching in Nairobi Province, Kenya." Kenyatta University - Unpublished PhD Thesis.

Beukes-Amiss, C.M. \& Chiware, E.R.T. (2006). The impact of diffusion of ICTs into educational practices, how good or how bad? A review of the Namibia situation. Available at: http://www.dspace.unam.na:8443/dspace/bitstream/1995/244/impact+ diffusionICTedupdf (Accessed 10 February 2007)

Bingimlas, K. A. (2009). "Barriers to the Successful Integration of ICT in Teaching and Learning Environments: A Review of the Literature." Eurasia Journal of Mathematics, Science \& Technology Education Vol. 5(3), pp. 235-245. Available online at: http://www.ejmste.com/v5n3/eurasiav5n3 bingimlas.pdf

Boakye, K. F. \& Banini, D. A. (2008). "Teacher ICT Readiness in Ghana.” In Kathryn T. Tchombe \& T. M. S. Karsenti (eds). ICT and Changing Mindsets in Education. Bamenda (Cameroon): Langaa RPCIG.

Brinkerhoef J. (2006). Effects of a long-duration, Professional Development Academy on Technology Integration Beliefs and Practices. Journal of Research on Technology in Education, (39):22-43.

Castells, M. (2000). The Information Age: Society and Culture Vol. III: End of Millennium. Oxford, Blackwell.

Chan, Foong-Mae (2002). "ICT in Malaysian Schools: Policy and Strategies." Center for the Research and Support of Educational Practice. Available online http://www.pdfking.net/ICT-in-Malaysian-Schools-Policy-and-Strategies--PDF.html. 
Journal of Education and Practice

ISSN 2520-467X (online)

Vol.4, Issue No.3, pp $56-87,2020$

www.carijournals.org

Colley, A. \& Comber C. (2003). Age and gender differences in computer use and attitudes among secondary school students: what has changed? Educational Research. Volume 45, Issue 2:155-165. Published online: 02 Dec 2010 - http://www.tandfonline.com/doi/abs/

Cox, M.; Abbott, C.; Webb, M.; Blakely, B.; Beauchamp, T.; \& Rhodes, V. (2004). ICT and Pedagogy - A Review of the Literature, ICT in Schools Research and Evaluation Series, 18. London: DfES/BECTA.

Davis, F. D. (1989). "Perceived Usefulness, Perceived Ease of Use, and User Acceptance of Information Technology." MIS Quarterly (13:3), pp. 319-339.

Davis, F. D., Bagozzi, R. P. \& Warshaw, P. R. (1989). "User Acceptance of Computer Technology: A Comparison of Two Theoretical Models." Management Science. 35(8). 982-1003.

Ertmer P. A. (1999). "Addressing First- and Second-order Barriers to Change: Strategies for Technology Integration." In Educational Technology, Research and Development Vol. 47, No. 4 (pp. 47-61).

Evoh, C. J. (2009a). "Collaborative Partnerships and the Application of ICTs in Secondary Education in South Africa." In Janet Salmons and Lynn Wilson (eds). Handbook of Research on Electronic Collaboration and Organizational Synergy Volume I. New York: Information Science Reference.

Evoh, C. J. (2009b). "Emerging Trajectories and Sustainability of ICTs in Educational Reforms in Africa: Exploring the Prospects of the Teacher Laptop Policy in South Africa." In Journal of Education for International Development Vol. 4:2 (pp. 21-33). Available online; http://www.equip123.net/JEID/articles/4_2/JEID4-2-FullIssue.pdf

Farrell, G. \& Isaacs, I. (2007). Survey of ICT and Education in Africa: A Summary Report, Based on 53 Country Surveys. Washington, DC: infoDev/World Bank. Available at http://www.infodev.org/en/Publication. 353.html

Fullan, M. (2001). The New Meaning of Educational Change ( $3^{\text {rd }}$ ed.). London: Routledge/Falmer.

Goodison, T. A. (2002). "Learning with ICT at Primary Level: Pupils' Perceptions." Journal of Computer Assisted Learning, 18, 282-295.

Government of Kenya (GoK) (2005). Sessional Paper No 1 of 2005: A Policy Framework For Education, Training and Research. Nairobi: Government Printers.

Hinostroza, J. E., Labbé, C. \& Claro, M. (2005). "ICT in Chilean Schools: Students' and Teachers' Access to and Use of ICT." An Interdisciplinary Journal on Humans in ICT Environments. Vol.1(2), pp.246-264. Available online: http://www.humantechnology.jyu.fi

Hittleman, D. R. \& Simon, A. J. (2006). Interpreting Educational Research: An Introduction for Consumers of Research. Upper Saddle River, N. J: Pearson Education, Inc.

Kenya SchoolNet (2003). Preparing a Workforce for the Evolving Information Economy: A Survey on ICT Access and Use in Kenya Secondary Schools. Nairobi: Summit Strategies Limited. 
Journal of Education and Practice

ISSN 2520-467X (online)

Vol.4, Issue No.3, pp $56-87,2020$

www.carijournals.org

Kiptalam, G. K., \& Rodrigues, A. J. (2010). "Internet utilization: A case of connected rural and urban secondary schools in Kenya." International Journal of Computing and ICT Research, 4(1), 49-63. Retrieved from http://ijcir.org/volume4-number1/article6.pdf

Kirschner, P., \& Selinger, M. (2003). "The State of Affairs of Teacher Education with Respect to Information and Communication Technology." Technology, Pedagogy and Education.12, 5-17.

Kozma, R. (ed.) (2003). Technology, Innovation and Educational Change: A Global Perspective. Eugene, OR: Information Society for Technology in Education [ISTE] Publications.

Lawless K. \& Pellegrino J. (2007). Professional Development in Integrating Technology into Teaching and Learning: Knowns, Unknowns and Ways to Pursue Better Questions and Answers. Review of Educational Research, 77 (4): 575-614.

Lau, B. T. \& Sim, C. H. (2008). "Exploring the extent of ICT adoption among Secondary School Teachers in Malaysia." International Journal of Computing and ICT Research, II (II), 19-36.

Lee, K. T. (2002). "Effective Teaching in the Information Era: Fostering an ICTbased Integrated Learning Environment in Schools." Asia-Pacific Journal for Teacher Education \& Development 5(1): pp. 21-45. Hong Kong Institute of Education. Accessed from: https://eprints.qut.edu.au/secure/00003909/01/

Loveless, A. \& Dore, B. (eds.) (2002). ICT in the Primary School: Learning and Teaching with ICT. Buckingham: Open University Press.

Ministry of Education (MoE), Kenya (2008). "Implementation of NEPAD e-Schools Demo: Draft Interim Evaluation Report on Progress." Nairobi - Unpublished report by the National Implementation Team.

Ministry of Education, Science \& Technology (MoEST), Kenya (2005). Kenya Education Sector Support Programme (KESSP) 2005-2010: Strategic Plan for the Development of School Infrastructure. Nairobi: Government Printers.

Mishra, P., \& Koehler, M. J, (2008). "Introducing Technological Pedagogical Content Knowledge." Paper presented at the Annual Meeting of the American Educational Research Association New York City, March 24-28, 2008.

Mishra, P., \& Koehler, M. J, (2006). "Technological Pedagogical Content Knowledge: A Framework for Teacher Knowledge." In Teachers College Record Vol. 108, No. 6, June 2006, pp. 1017-1054.

Mugenda, O. M. \& Mugenda, A. G. (2013). Research Methods: Quantitative and Qualitative Approaches. Nairobi: ACTS Press.

Mugo, D. G. (2007). The Successes and Challenges Facing NEPAD e-School Project: A case study of Mumbi Girls' Secondary School, Murang'a, Kenya. Nairobi: Kenyatta University - Unpublished Master of Education Thesis.

Mungai, M. (2011). 12 challenges facing computer education in Kenyan schools. Retrieved from $\quad$ http://www.ictworks.org/news/2011/09/12/12-challenges-facing-computereducation-kenyan-schools? 
Journal of Education and Practice

ISSN 2520-467X (online)

Vol.4, Issue No.3, pp $56-87,2020$

$\underline{\text { www.carijournals.org }}$

Murray, L. \& Lawrence, B. (2000). Practitioner-Based Enquiry: Principles for Postgraduate Research. London: Falmer Press.

Ndawula, S.; Kahuma, B.; Mwebembezi, J. \& Masagazi, J. (2013). "Getting Schools Ready for Integration of Pedagogical ICT: The Experience of Secondary Schools in Uganda." International Journal of Academic Research in Business and Social Sciences, Vol. 3, No. 2. Available online: http://www.hrmars.com/journals

Ndiku, L. (2003). "The Problems Encountered by School Personnel in the Implementation of Computer Use in Secondary Schools in Uasin Gishu District." Eldoret: Moi University Unpublished Thesis.

NEPAD e-Africa Commission (2007). Executive Summary of the Draft Report for the NEPAD e-Schools Business Plan. Pretoria: Author

Nyagowa, H. O.; Ocholla, D. N. \& Mutula, S. M. (2012). Evaluation of Success of NEPAD's Pilot e-Schools in Kenya: An overview. Available online at: www.lis.uzulu.ac.za/.../Nyagowa\%20and\%200cholla\%20and\%20Mutula\%20SCECS...

Ogutu, J. O. (2008). "The Impact of ICT Integration in the Six NEPAD e-Schools in Kenya." Nairobi: University of Nairobi - Unpublished M.A. Thesis.

Orodho, J. O. (2004). Techniques of Research Proposals and Reports. Nairobi: Masola Publishers.

Osakwe N.R. (2010). "The Influence of Information and Communication Technology (ICT) on Teacher Education and Professional Development in Delta State, Nigeria." Asian Journal of Information Technology Volume: 9|Issue: 5| Page No.: 280-285. In http://scialert.net/asci/author.php? author=N.R.\&last=Osakwe

O’Dwyer, L. M., Russell, M. \& Bebell, D. J. (2004). "Identifying Teacher, School and District Characteristics Associated with Elementary Teachers' Use of technology: A multilevel perspective." Education Policy Analysis Archives, 12, 1-33.

Pelgrum, W. J. (2001). Obstacles to the integration of ICT in education: results from a worldwide educational assessment. Computers \& Education, 37, 163-178.

Picciano, A. G. (2004). Educational Research Primer. London: Continuum.

Roblyer, M. D. (2006). Integrating Educational Technology into Teaching (4 ${ }^{\text {th }}$ ed.). Upper Saddle River, N.J.: Pearson Education, Inc.

Rogers, E. M. (2003). Diffusion of Innovations (5th Ed.). New York: The Free Press.

Schiller, J. (2003). Working with ICT Perceptions of Australian Principals. Journal of Educational Administration, 41(2), 171-185.

Scott, D. \& Usher, R. (2010). Researching Education: Data, Methods and Theory in Educational Enquiry (2 ${ }^{\text {nd }}$ ed). London: Continuum Publishing Co.

Scrimshaw, P. (2004). Enabling Teachers to Make Successful Use of ICT. British Educational Communications and Technology Agency (Becta).

Smeets, E. (2005). "Does ICT Contribute to Powerful Learning Environments in Primary Education?" Computers \& Education, 44, 343-355. 
Journal of Education and Practice

ISSN 2520-467X (online)

Vol.4, Issue No.3, pp 56 - 87, 2020

$\underline{\text { www.carijournals.org }}$

Statistics Canada (2012). Education indicators in Canada: Report of the Pan-Canadian Education Indicators Program. Ottawa: Author. Available at http://wellbeing.esdc.gc.ca/misme-iowb/.3ndic.1t.4r@-eng.jsp?iid=28

Steketee, C. (2006). "Modelling ICT Integration in Teacher Education Courses Using Distributed Cognition as a Framework." Australasian Journal of Educational Technology, 22 (1), 126 - 144 [Electronic version].

Tang, P. S., \& Ang, P. H. (2002). "The Diffusion of Information Technology in Singapore Schools: A Process Framework." New Media \& Society, 4, 457-478.

Tearle, P. (2004). "A Theoretical and Instrumental Framework for Implementing Change in ICT in Education." Cambridge Journal of Education, 34, 331-351.

Tella, A., Tella, A., Toyobo, O. M., Adika, L. O. \& Adeyinka, A. A. (2007). An Assessment of Secondary School Teachers Uses of ICT's: Implications for Further Development of ICT's Use in Nigerian Secondary Schools. The Turkish Online Journal of Educational Technology - Volume 6 Issue 3 Article 1.

The Robert Gordon University Aberdeen (2004). Teachers ICT skills and knowledge needs. Final Report to SOEID Section Three. Available online at: http://www.rguedu.org \{Accessed 10 February 2007\}.

Trucano, M. (2005). Knowledge Maps: ICTs in Education. Washington, DC: infoDev/World Bank. Available online: http://www.infodev.org/articles/

UNESCO (2005). Toward the Knowledge Society: UNESCO World Report. Paris: UNESCO. From: www.unesco.org/en/worldreport (Accessed 27/11/2006).

UNESCO (2000). Education for All: Meeting our Collective Commitments; Expanded Commentary on the Dakar Framework for Action. Paris: UNESCO.

UNGA (2000). United Nations Millennium Declaration. New York: UNO.

U.S. Department of Education, National Center for Education Statistics. (2010). Teachers' Use of Educational Technology in U.S. Public Schools: 2009 (NCES 2010-040). Available online at: https://nces.ed.gov/fastfacts/display.asp?id=46

Vekiri, I. \& Chronaki, A. (2008). Gender issues in technology use: Perceived social support, computer self-efficacy and value beliefs, and computer use beyond school. Computers \& Education, Vol.51:1392-1404. Available online: www.sciencedirect.com

Venkatesh, V. (2000). "Determinants of Perceived Ease of Use: Integrating Perceived Behavioral Control, Computer Anxiety and Enjoyment into the Technology Acceptance Model.” Information Systems Research (11:4), pp. 342- 365.

Venkatesh,V. \& Bala, H. (2008). "Technology Acceptance Model 3 and a Research Agenda on Interventions.” Decision Sciences Vol. 39 No. 2, pp. 273-315.

Venkatesh, V., \& Davis, F. D. (2000). “A Theoretical Extension of the Technology Acceptance Model: Four Longitudinal Field Studies.” Management Science (45:2), pp. 186-204.

Venkatesh, V.; Morris, M. G.; Davis, G. B. \& Davis F. D. (2003). "User Acceptance of Information Technology: Toward a Unified View." MIS Quarterly Vol. 27 No. 3, pp. 425-478. 
Journal of Education and Practice

ISSN 2520-467X (online)

Vol.4, Issue No.3, pp 56 - 87, 2020

www.carijournals.org

Waxman, H., Connell, M. \& Gray, J. (2002). A Quantitative Synthesis of Recent Research on the Effects of Teaching and Learning with Technology on Student Outcomes. Naperville, IL: North Central Regional Education Laboratory.

Wiersma, W. \& Jurs, S. G. (2005). Research Methods in Education: An Introduction ( ${ }^{\text {th }}$ ed). Boston: Allyn \& Bacon.

Wims, P. \& Lawler, M. (2007). Investing in ICTs in educational institutions in developing countries: An evaluation of their impact in Kenya. International Journal of Education and Development using Information and Communication Technology (IJEDICT), 2007,
Vol.
3 ,
Issue
1 ,
pp.
5-22.
Available
online:

http://ijedict.dec.uwi.edu/printarticle.php?id=241amp; layout=html\&layout=html 